CrossMark \&lick for updates

Cite this: Dalton Trans., 2014, 43, 16227

\title{
Syntheses of sterically shielded stable carbenes of the 1,2,4-triazole series and their corresponding palladium complexes: efficient catalysts for chloroarene hydrodechlorination $\dagger$
}

\author{
Nataliya V. Glinyanaya, ${ }^{a}$ Vagiz Sh. Saberov, ${ }^{a}$ Nikolai I. Korotkikh, ${ }^{* a}$ Alan H. Cowley, \\ Rachel R. Butorac, ${ }^{b}$ Daniel A. Evans, ${ }^{\text {b }}$ Tatyana M. Pekhtereva, ${ }^{a}$ Anatolii F. Popov ${ }^{a}$ and \\ Oles P. Shvaika ${ }^{a}$
}

\begin{abstract}
The new sterically shielded 1,3,4-trisubstituted 1,2,4-triazol-5-ylidenes $\mathbf{8} \mathbf{b}$ - $\mathbf{d}$ were synthesized by a three step method starting from 2-phenyl-1,3,4-oxadiazole. The syntheses of palladium complexes $\mathbf{9 a - d}$ and $10 a-d$ (including the sterically shielded derivatives $9 c, d$ and $10 a-d$ ) were carried out via the reactions of the stable carbenes $\mathbf{8} \mathbf{a}-\mathbf{d}$ with palladium halogenide salts in THF or toluene solution. Complexes $\mathbf{9 c , d}$ and $10 \mathbf{a}-\mathbf{d}$ were found to be excellent catalysts for the reductive dechlorination (hydrodechlorination) of $p$-dichlorobenzene. The structures of $\mathbf{8 c}, \mathbf{9} \mathbf{a}, \mathbf{b}$, and $10 \mathbf{a}$ were determined by single-crystal $\mathrm{X}$-ray diffraction.
\end{abstract}

Received 7th May 2014,

Accepted 24th June 2014

DOI: 10.1039/c4dt01353k

www.rsc.org/dalton

\section{Introduction}

Recently, stable carbenes have proven to be versatile reagents and catalysts for many important organic reactions. ${ }^{1-3}$ Heteroaromatic imidazol-2-ylidenes and 1,2,4-triazol-5-ylidenes are particularly well known examples of stable carbenes. ${ }^{4}$ The former type has been studied extensively; however, as individual compounds, 1,2,4-triazol-5-ylidenes are relatively unexplored. The first stable carbene of this type, namely a 1,3,4triphenyl substituted derivative, was prepared and investigated by Enders and co-workers. ${ }^{5,6}$ Subsequently, new types of 1-adamantyl- and 1-tert-butyl substituted 1,2,4-triazol-5-ylidenes have been described ${ }^{7,8}$ along with their transformations upon heating ${ }^{9}$ and reaction with a malonic ester. ${ }^{10}$ Biscarbenes with enhanced thermal and chemical stabilities featuring conjugated 3,3'- and 4,4'-bis-1,2,4-triazol-5-ylidenes have been synthesized and used as ligand supports for copper(I) complexes. ${ }^{11,12}$ In a series of studies 1,2,4-triazol-5-ylidene complexes were prepared in situ from the corresponding salts (for the latest see,

\footnotetext{
${ }^{a}$ The L.M. Litvinenko Institute of Physical Organic and Coal Chemistry, Ukrainian Academy of Sciences, 70, R. Luxemburg, Donetsk, 83114, Ukraine.

E-mail: nkorotkikh@ua.fm; Fax: +(380 62)311-68-30; Tel: +(380 62)311-68-35

${ }^{b}$ Department of Chemistry, The University of Texas at Austin, 1 University Station A5300, Austin, Texas 78712-0165, U.S.A.. E-mail: acowley@cm.utexas.edu; Tel: +1 (512)471-74-84

$\dagger$ Electronic supplementary information (ESI) available: X-ray crystallographic data for $\mathbf{8 c}, 9 \mathbf{9 a , b}, \mathbf{1 0 c}$; NMR spectra; CIF files for 8c, 9a,b, 10c. CCDC 1000720 (8c), 1000718 (9a), 1000719 (9b) and 1000721 (10a). For ESI and crystallographic data in CIF or other electronic format see DOI: 10.1039/c4dt01353k
}

for example, ref. 13-15). Furthermore, 1,3,4-triphenyl-1,2,4triazol-5-ylidene has proven to be not only an effective catalyst for organic reactions (e.g. benzoin and Stetter condensations), ${ }^{2}$ but also a ligand for metal catalyzed reactions. ${ }^{3}$ To the best of our knowledge, sterically shielded carbenes of this general type have not been synthesized thus far. However, such compounds could prove to be useful for catalytic applications and for the development of new methods for haloarene hydrodehalogenation.

Halogenaromatic compounds (haloarenes) are widely used as e.g. pesticides, pharmaceuticals, and high-temperature fluids. Unfortunately, most of the aforementioned materials are highly toxic. Moreover, these toxic haloarenes have accumulated in large amounts throughout the world. Several of these haloarene compounds require particular attention, specifically DDT, hexachlorobenzene, dioxins, polychlorodibenzofurans (furans), and polychlorobiphenyls. ${ }^{16}$ All of the foregoing compounds were included in the Stockholm Convention of May $22^{\text {nd }} 2001$ in a list of the 12 most hazardous "persistent organic pollutants" (POPs). The safe management of these troublesome toxic POPs represents a persistent environmental concern.

The most common pathways for haloarene detoxification are as follows: (1) oxidative methods (combustion at high temperatures or oxidation in critical water, etc.), (2) reductive methods such as catalytic reduction with hydrogen, reduction with metals and nanometals, and (3) biodegradation methods. ${ }^{17}$ The first group of methods for haloarene detoxification has some disadvantages such as the use of high 
temperature and/or high pressure conditions, the difficulty in recovering the vaporized polychloroarenes, and the high risk of producing dioxins. The second group of detoxification methods also presents some unfavorable aspects, particularly those that concern the formation of corrosive hydrohalogenides and the high pressures that are necessary for hydrogenation and acidic reductions, ${ }^{18}$ the use of dangerous or expensive reducing reagents such as alkali metals and metalorganic compounds, ${ }^{19}$ microwave techniques, ${ }^{20}$ all of which result in low decomposition rates or efficiencies. For example, the promising use of metallic calcium in ethanol for hydrodehalogenation requires large quantities of the metal (10-40 fold excess per $1 \mathrm{Cl}$ ) and involves the formation of several by-products of the ring reduction. ${ }^{21-23}$ Noble metal nanoparticles allow recycling of the catalyst. However, they require approximately $1 \mathrm{~mol} \%$ Pd to achieve the necessary activity for detoxification. $^{24,25}$ Furthermore, biodegradation methods with aerobic microbes are only suitable for the reduction of low halogenated arenes and hence they are not useful as a general detoxification method (such organisms are contained in small amounts in the first few mm of soil). ${ }^{16,17}$ Moreover, anaerobic microorganisms are suitable for reductive dechlorination (hydrodechlorination) which results in the conversion of more chlorinated hydrocarbons. However, such species only react with $m$ - and $p$-substituted compounds and do not activate $o$-substituted haloarenes.

Thus, among the known methods, catalytic reductive dehalogenation (hydrodehalogenation) promises the greatest potential for success. In the interest of achieving high catalytic activities and cost effectiveness, catalytic reductive dehalogenation could represent the best solution for the neutralization of toxic POPs. Moreover, palladium carbene complexes are well known to be the suitable catalysts for the foregoing reaction. For example, it is known that an in situ generated catalyst based on $\mathrm{Pd}(\mathrm{dba})_{2}$ and 1,3-disubstituted imidazolin-2-ylidenes affords high yields of hydrodehalogenation products when carried out in dioxane at $100{ }^{\circ} \mathrm{C}$ (TON up to $28-50$, TOF up to 28-50 h ${ }^{-1}$ ). ${ }^{26}$ Compound 1 (Fig. 1) provides moderate catalytic

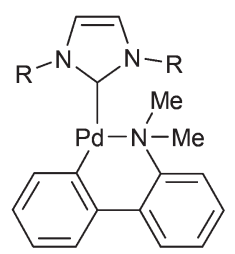

1

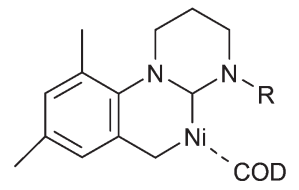

4

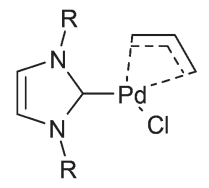

2

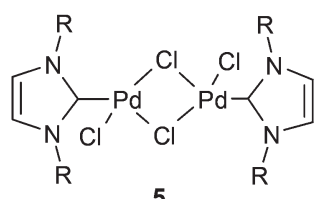

5

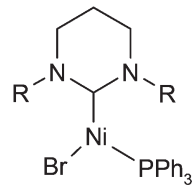

3
Fig. 1 Palladium and nickel catalysts for the hydrodehalogenation reactions (1, 2, $5 \mathrm{R}=\operatorname{Dipp}$ (2,6-diisopropylphenyl); 3, $4 \mathrm{R}=\operatorname{Mes}(2,4,6$ trimethylphenyl). efficiencies for the reactions of monochlorobenzenes at room temperature $^{27}$ (TON 100, TOF $200 \mathrm{~h}^{-1}$ ) and complex 2 has been shown to be active for the hydrodehalogenation of p-dichlorobenzene at $60{ }^{\circ} \mathrm{C}\left(\right.$ TON 194, TOF $\left.111 \mathrm{~h}^{-1}\right) .{ }^{28}$ Furthermore, the use of microwave irradiation at $120{ }^{\circ} \mathrm{C}$ resulted in the highest rate for this reaction. In this case, a virtually quantitative yield of the product was obtained in only 2 min (TON 4000, TOF $120000 \mathrm{~h}^{-1}$ for $p$-chlorotoluene; TON 3800, TOF $114000 \mathrm{~h}^{-1}$ for $p$-dichlorobenzene). ${ }^{28}$

The catalytic efficiency of the nickel complex 3 that was prepared via the reaction of $\mathrm{Ni}\left(\mathrm{PPh}_{3}\right)_{2} \mathrm{Br}_{2}$ with the corresponding carbene $^{29}$ is not high for the hydrodebromination transformation of $p$-bromofluorobenzene or for the hydrodechlorination of $p$-chlorofluorobenzene (activated haloarenes) (TON 15-22 and TOF $4-44 \mathrm{~h}^{-1}$ at $25^{\circ} \mathrm{C}$ ).

The nickel(I) complex 4 was used for the hydrodefluorination of fluorobenzenes. ${ }^{30}$ It was found that in the presence of $\mathrm{Et}_{2} \mathrm{CHONa}$ at $100{ }^{\circ} \mathrm{C}$ catalysts of the type $\mathrm{L}_{2} \mathrm{Ni}$ are less efficient for hydrodehalogenation (TON 12 and TOF $4 \mathrm{~h}^{-1}$ for $\mathrm{L}=\mathrm{IMes}$ ) than LNi (TON 18-31 and TOF 6-10 $\mathrm{h}^{-1}$, respectively). Taken collectively, complexes 1-4 exhibit insufficient catalytic activities. However, the highest efficiencies for polyhalogenated arenes were obtained with the dimeric $\left(\mathrm{IPrPdCl}_{2}\right)_{2}$ catalyst 5 $(\mathrm{R}=\mathrm{Dipp})^{31}$ (for the hydrodehalogenation of 1,2,4,5-tetrachlorobenzene in isopropanol at $80{ }^{\circ} \mathrm{C}$ TON 19650 and TOF $819 \mathrm{~h}^{-1}$ and for the reaction of 2,2',3,3'-tetrachlorobiphenyl with a TON of 10000 and with a TOF $417 \mathrm{~h}^{-1}$, respectively).

Given the foregoing information, sterically shielded 1,2,4triazol-5-ylidenes were investigated as ligands for haloarene hydrodehalogenation catalysis. In the present contribution, we describe (i) the syntheses of new sterically shielded carbenes 1-alkyl-3,4-diaryl-1,2,4-triazol-5-ylidenes; (ii) the syntheses of mono- and biscarbene palladium halogenide complexes of the 1,2,4-triazol-5-ylidenes; (iii) the X-ray crystal structures of the sterically shielded carbene 1-tert-butyl-3-phenyl-4-(2,6-diisopropylphenyl)-1,2,4-triazol-5-ylidene; three $\mathrm{PdI}_{2}$ and $\mathrm{PdCl}_{2}$ carbene complexes bis-[1-tert-butyl-3-phenyl-4-(4-bromophenyl)-1,2,4-triazol-5-yliden]palladium chloride, bis-[1-tertbutyl-3-phenyl-4-(4-bromophenyl)-1,2,4-triazol-5-yliden]palladium iodide and the sterically shielded [1-tert-butyl-3-phenyl-4(2,6-diisopropylphenyl)-1,2,4-triazol-5-yliden]palladium chloride; (iv) catalytic efficiencies of the foregoing complexes with respect to the hydrodechlorination of $p$-dichlorobenzene.

\section{Results and discussion}

\section{Synthesis of carbenes and their palladium complexes}

In order to obtain the desired carbene complexes, along with the known carbene $\mathbf{8 a},{ }^{9}$ a series of new stable carbenes $\mathbf{8 b}-\mathbf{d}$ was synthesized in the following three stages: (1) syntheses of sterically hindered 4-substituted 3-phenyl-4-aryl-1,2,4-triazoles $\mathbf{6 b , c}$ via the ring transformation of 2-phenyl-1,3,4-oxadiazole with the appropriate anilines, (2) quaternization of 1,2,4-triazoles 6b,c using sterically hindered alkylhalogenides (tertbutyl iodide and 1-bromoadamantane), (3) deprotonation of 


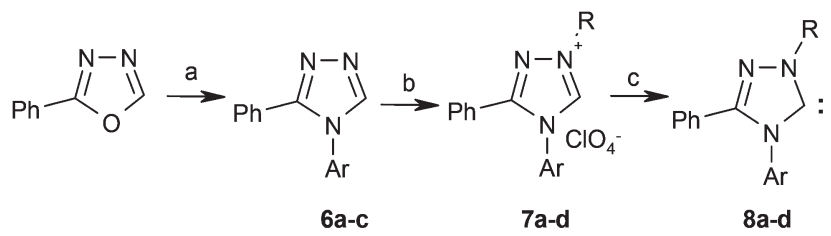

Scheme 1 Syntheses of carbenes 8a-d. Reaction conditions: (a) $\mathrm{ArNH}_{2}$, TFA, o-DCB, $190{ }^{\circ} \mathrm{C}, 12 \mathrm{~h}$; (b) (1) RX, AcOH, $120{ }^{\circ} \mathrm{C}, 10-18$ h; (2) $\mathrm{NaClO}_{4}$; (c) $t-\mathrm{BuOK}, \mathrm{PhMe}, \mathrm{i}-\mathrm{PrOH}$, r.t. Compounds: $6 \mathrm{a} \mathrm{Ar}=4-\mathrm{BrC}_{6} \mathrm{H}_{4} ; 6 \mathrm{~b} \mathrm{Ar}=$ Mes; $6 \mathrm{c} \mathrm{Ar}=\mathrm{Dipp} ; 7 \mathrm{a}, 8 \mathrm{a} \mathrm{R}=t-\mathrm{Bu} ; \mathrm{Ar}=4-\mathrm{BrC}_{6} \mathrm{H}_{4} ; 7 \mathrm{~b}, 8 \mathrm{~b} \mathrm{R}=1-\mathrm{Ad} ; \mathrm{Ar}=$ Mes; 7c, 8c R = $t$-Bu; $A r=$ Dipp; 7d, 8d R = 1-Ad; $A r=$ Dipp; Dipp = $2,6-\mathrm{i}-\mathrm{Pr}_{2} \mathrm{C}_{6} \mathrm{H}_{3}$
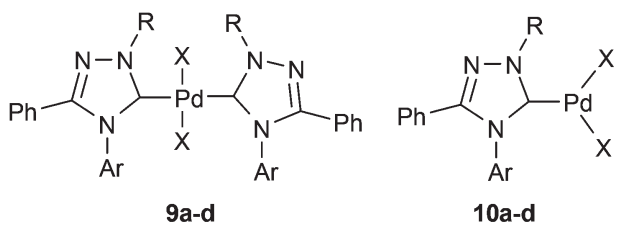

Fig. 2 Mono and biscarbene palladium complexes $(9 \mathrm{a} X=\mathrm{Cl}, \mathrm{R}=t$ - $\mathrm{Bu}$, $\mathrm{Ar}=p-\mathrm{BrC}_{6} \mathrm{H}_{4} ; 9 \mathrm{bX}=\mathrm{I}, \mathrm{R}=t-\mathrm{Bu}, \mathrm{Ar}=p-\mathrm{BrC}_{6} \mathrm{H}_{4} ; 9 \mathrm{cX}=\mathrm{I}, \mathrm{R}=\mathrm{Ad}, \mathrm{Ar}=$ Mes; $9 \mathrm{~d} X=\mathrm{I}, \mathrm{R}=t-\mathrm{Bu}, \mathrm{Ar}=\mathrm{Dipp} ; 10 \mathrm{a} X=\mathrm{Cl}, \mathrm{R}=t-\mathrm{Bu}, \mathrm{Ar}=\mathrm{Dipp} ; 10 \mathrm{~b} \mathrm{X}$ $=\mathrm{I}, \mathrm{R}=t-\mathrm{Bu}, \mathrm{Ar}=\mathrm{Dipp} ; 10 \mathrm{c} \mathrm{X}=\mathrm{Cl}, \mathrm{R}=\mathrm{Ad}, \mathrm{Ar}=\mathrm{Dipp} ; 10 \mathrm{~d} \mathrm{X}=\mathrm{I}, \mathrm{R}=\mathrm{Ad}$, $\operatorname{Ar}=$ Dipp).

the aforementioned salts $\mathbf{7 b}$-d $\mathbf{d}$ using potassium tert-butoxide in a mixture of toluene and isopropanol akin to previously published work from our laboratory ${ }^{7}$ (Scheme 1), most of which $(\mathbf{8 b}-\mathbf{d})$ include sterically hindered groups $(t-\mathrm{Bu}$ or 1-Ad in position 1 with Mes or Dipp in position 4).

The syntheses of the new biscarbene complexes 9a-d (Fig. 2) were carried out via the direct reaction of the free carbenes 8a-d with palladium halogenides (chloride and iodide) in a molar ratio of $2: 1$ in THF solution according to the pertinent literature method. ${ }^{32}$ An analogous method was used for the syntheses of the monocarbene complexes 10a-d using the appropriate molar ratio of $1: 1$. For purposes of comparison, the known complex 5 was prepared via the reaction of the appropriate 1,3-diarylimidazol-2-ylidene with $\mathrm{Pd}(\mathrm{PhCN})_{2} \mathrm{Cl}_{2}$ according to the literature procedure. ${ }^{31}$

Compounds 6a-c, 7a-d, 8a-d, 9a-e, 10a-d were characterized by ${ }^{1} \mathrm{H}$ and ${ }^{13} \mathrm{C}$ NMR spectroscopy, and their elemental compositions were established on the basis of elemental analysis. The ${ }^{13} \mathrm{C}$ NMR spectra of the sparingly soluble complexes $\mathbf{9 c}, \mathbf{d}$ and $\mathbf{1 0 b}, \mathbf{d}$ were recorded in the solid state. In the case of the ${ }^{1} \mathrm{H}$ NMR spectra of triazoles $\mathbf{6} \mathbf{b}, \mathbf{c}$ with the exception of the specific signals for the mesityl or dipp groups, the resonances of the meso-protons $\mathrm{CHN}$ were evident $(\delta 8.73,8.88 \mathrm{ppm}$ in DMSO- $\mathrm{d}_{6}$ ). In the case of the spectra of the triazolium salts 7a-d the NMR signals were shifted significantly downfield ( $\delta$ 10.61-10.91 ppm). It is noteworthy that two forms of the triazole $\mathbf{6 c}$ were detected in $\mathrm{CDCl}_{3}$ solution. The NMR spectrum of one of these forms was characterized on the basis of different signals for the methyl groups $(\delta 0.90,1.10 \mathrm{ppm})$ and the presence of an upfield signal for the methine $\mathrm{CH}$-groups $(\delta$ $2.37 \mathrm{ppm}$ ) of the corresponding isopropyl fragments. The other form was evident from the presence of only one signal for the methyl groups ( $\delta 1.19 \mathrm{ppm})$ and a downfield signal for the methine $\mathrm{CH}$-groups ( $\delta 3.02 \mathrm{ppm})$.

The meso-proton $\mathrm{CHN}$ resonances for these forms were found at 8.10 and $8.30 \mathrm{ppm}$, respectively. Presumably, the second form relates to a symmetrical structure with a close to $90^{\circ}$ angle for the $\mathrm{N}(4)$-aryl group. On the other hand, the alternate form could be a rotational form with a smaller bond angle. In DMSO- $\mathrm{d}_{6}$ solution the second form converted to the first one (the pertinent signals were located at $\delta 0.88,1.09$, and $2.24 \mathrm{ppm}$, respectively). Presumably for the same reason, in DMSO- $\mathrm{d}_{6}$ solution, salt 7c shows only the first form of the isomers $(\delta 0.88,1.09$, and $2.24 \mathrm{ppm})$. However, the NMR spectrum of salt $\mathbf{7 d}$ in $\mathrm{CDCl}_{3}$ corresponds to only the first form ( $\delta 0.91,1.21$, and $2.24 \mathrm{ppm}$, respectively). Interestingly, compounds $\mathbf{6 b}, \mathbf{c}$ were also obtained recently ${ }^{33}$ by a similar method to the one described above. Following purification, only one form of this compound was isolated.

The most useful information, for carbenes $\mathbf{8 a}-\mathbf{d}$, are the ${ }^{13} \mathrm{C}$ NMR signals for the carbene carbon atom $\mathrm{C}(5)$ ( $\delta$ 211.1-212.7 ppm). It was found that the NMR signals for complexes $\mathbf{9 a - d}$ and $\mathbf{1 0 a}-\mathbf{d}$ are shifted upfield ( $\delta$ 153.3-171.9 ppm). Interestingly, two closely spaced resonances were detected for compound $\mathbf{9 b}$ in $\mathrm{CDCl}_{3}$ solution. These resonances can be assigned to the trans-trans and cistrans isomers of $\mathbf{9 b}$ (the first designation relates to the disposition of the rotating triazole rings with respect to each other and the second one relates to the disposition of the halogen atoms at the metal center). The first isomer was isolated in a pure state and subsequently characterized on the basis of a single crystal X-ray diffraction study. The ${ }^{1} \mathrm{H}$ and ${ }^{13} \mathrm{C}$ NMR spectra for complex $10 a$ in $\mathrm{CDCl}_{3}$ solution exhibited two forms, presumably due to rotation of the N(4)-aromatic ring. The presence of two different signals of the tert-butyl protons confirmed this interpretation ( $\delta 2.18$ and $2.29 \mathrm{ppm})$. However, only one methyl signal was evident in the ${ }^{13} \mathrm{C}$ NMR spectrum ( $\delta 31.4 \mathrm{ppm}$ ), along with one signal for the ipso-C atom ( $\delta 64.3 \mathrm{ppm}$ ). Furthermore, the presence of two groups of methyl and $\mathrm{CH}$-resonances is evident in the ${ }^{1} \mathrm{H}$ NMR spectra ( $\delta$ 0.54-0.70 ppm and 1.16-1.57 ppm, and 2.50, $2.61 \mathrm{ppm}$, respectively). These resonances indicate the existence of nonequivalent isopropyl and methyl groups in both isomers. However, only one isomer was detected in the single crystal $\mathrm{X}$-ray structure (see below).

The solid state ${ }^{13} \mathrm{C}$ NMR spectra of complexes $9 \mathbf{c}, \mathbf{d}$ and $\mathbf{1 0 c}$, d exhibited only one isomeric form for each compound (single resonances are apparent for the i-Pr $\mathrm{CH}$, Ad ipso-C, $\mathrm{C}(3)$ and $\mathrm{C}(5) \mathrm{Pd}$ atoms at $\delta$ 47.4-49.1, 64.1-65.6, 148.2-156.4, and 154.9-171.9 ppm, respectively). The C(5)Pd signals for the chloride complexes (10a,c) were shifted upfield $(\delta$ 153.3$154.9 \mathrm{ppm})$ relative to those for similar resonances ( $\delta$ 167.0$171.9 \mathrm{ppm})$ that were observed for the iodide complexes $(\mathbf{9 c}, \mathbf{d}$ and $\mathbf{1 0 b}, \mathbf{d}$ ). Four resonances were evident for the carbenoid carbon of complex 10b and can be explained by the presence of four fixed rotational forms in the solid state. The ${ }^{1} \mathrm{H}$ NMR spectrum for 10b in $\mathrm{DMSO}^{-\mathrm{d}_{6}}$ solution indicates that only 
two forms of the complex were present in solution (for the i-Pr group $\mathrm{CH}_{3} \mathrm{C} \delta$ 0.62, 1.36; $\mathrm{CHC} 2.94 \mathrm{ppm}$ and $\mathrm{CH}_{3} \mathrm{C}$ $\delta$ 0.83, 1.25; CHC $4.11 \mathrm{ppm}$ and one signal of the $t-\mathrm{Bu} \mathrm{CH}_{3} \mathrm{C}$ group).

\section{X-ray diffraction studies}

The single crystals of compound $\mathbf{8 c}$ were grown from toluene solution and studied subsequently by X-ray diffraction. The structure of $8 \mathrm{c}$ is presented in Fig. 3 and the bond lengths $(\AA)$, bond orders, bond angles and dihedral angles (degrees) for structure $\mathbf{8 c}$ are presented in Table 1 . As can be seen from these data, the planar structure of $\mathbf{8 c}$ is reminiscent of those for the 1,2,4-triazol-5-ylidenes. ${ }^{9,10,34}$ The bond angle at the carbene carbon atom is approximately $100.5^{\circ}$ and the high bond order of 1.718 for the $\mathrm{C}(1)-\mathrm{N}(3)$ bond implies a substantial ylide contribution to the carbene structure. Moreover, the $\mathrm{C}(2)$-aromatic ring is twisted relative to the plane of the triazole ring by $36.3^{\circ}$ (the bond order is 1.284), and furthermore the $\mathrm{N}(1)$-aromatic ring is twisted almost orthogonally with respect to the triazole ring $\left(87.4^{\circ}\right)$ (the bond order is 1.139).

The single crystals of the palladium complexes $\mathbf{9 a , b}$ and 10a that were used for the X-ray diffraction studies were grown from acetonitrile. The crystal structures of $\mathbf{9 a , b}$ and $\mathbf{1 0 a}$ are displayed in Fig. 4-6 and the bond lengths, bond orders, bond angles and dihedral angles are presented in Tables 2-4.

Complexes 9a,b adopt predominant trans-trans isomeric orientations. The bond orders for $\mathrm{N}(2)-\mathrm{C}(1)$ in these molecules ( $p$ 1.770-1.782) closely resemble that of the initial carbene

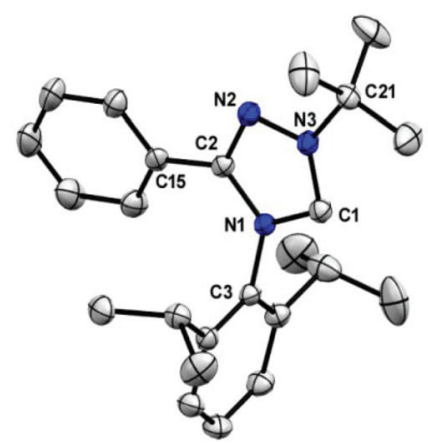

Fig. 3 POV-Ray diagrams for 1-tert-butyl-3-phenyl-4-(2,6-diisopropylphenyl)-1,2,4-triazol-5-ylidene $8 \mathrm{c}$ with thermal ellipsoids displayed at $50 \%$ probability. All hydrogen atoms have been removed for clarity.

Table 1 Selected bond lengths and angles for carbene 8c

\begin{tabular}{|c|c|c|c|c|}
\hline Bond & Length $(\AA)$ & $\begin{array}{l}\text { Bond } \\
\text { order }\end{array}$ & Angle & $\circ$ \\
\hline $\mathrm{C}(1)-\mathrm{N}(3)$ & $1.3491(14)$ & 1.718 & $\mathrm{~N}(3)-\mathrm{C}(1)-\mathrm{N}(1)$ & $100.53(9)$ \\
\hline $\mathrm{C}(1)-\mathrm{N}(1)$ & $1.3843(15)$ & 1.516 & $\mathrm{~N}(1)-\mathrm{C}(2)-\mathrm{N}(2)-\mathrm{N}(3)$ & $-0.48(11)$ \\
\hline $\mathrm{C}(2)-\mathrm{N}(1)$ & $1.3860(14)$ & 1.506 & $\mathrm{~N}(1)-\mathrm{C}(1)-\mathrm{N}(3)-\mathrm{C}(21)$ & $177.70(10)$ \\
\hline $\mathrm{C}(2)-\mathrm{N}(3)$ & $1.3134(14)$ & 1.923 & $\mathrm{~N}(1)-\mathrm{C}(2)-\mathrm{C}(9)-\mathrm{C}(10)$ & $36.3(6)$ \\
\hline $\mathrm{C}(2)-\mathrm{C}(15)$ & $1.4781(15)$ & 1.284 & $\mathrm{C}(1)-\mathrm{N}(1)-\mathrm{C}(3)-\mathrm{C}(4)$ & $87.40(13)$ \\
\hline $\mathrm{C}(3)-\mathrm{N}(1)$ & $1.4498(13)$ & 1.139 & - & - \\
\hline $\mathrm{N}(2)-\mathrm{N}(3)$ & $1.3834(13)$ & 1.336 & - & - \\
\hline $\mathrm{N}(3)-\mathrm{C}(21)$ & $1.4917(14)$ & 0.898 & - & - \\
\hline
\end{tabular}

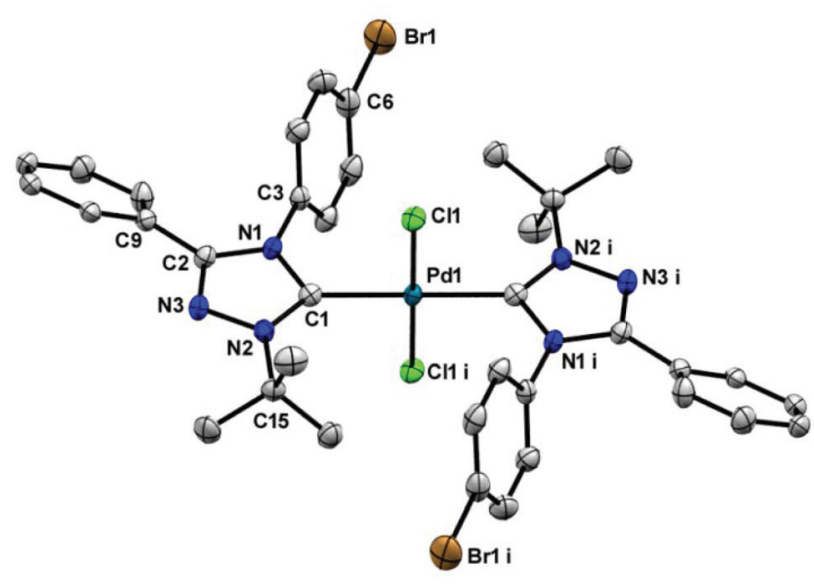

Fig. 4 POV-Ray diagrams for bis-(1-tert-butyl-3-phenyl-4-bromophenyl-1,2,4-triazol-5-yliden)palladium chloride 9a with thermal ellipsoids displayed at $50 \%$ probability. All hydrogen atoms have been removed for clarity.

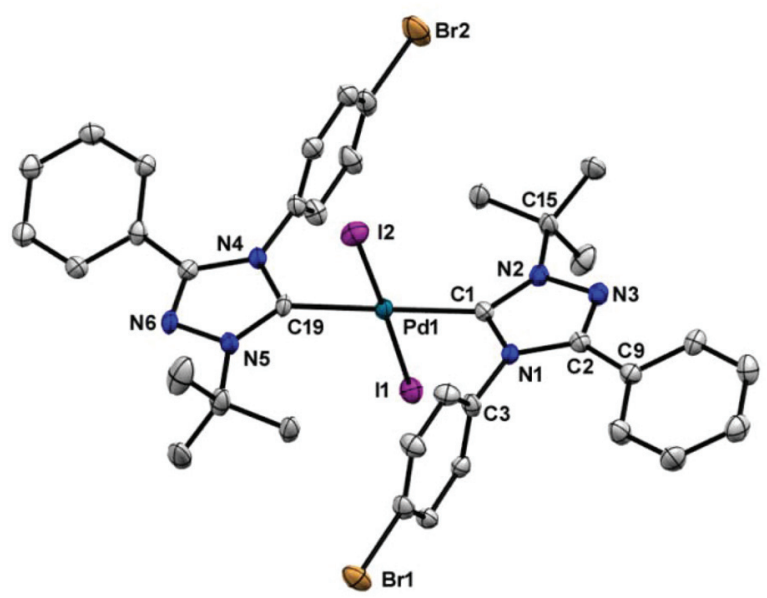

Fig. 5 POV-Ray diagrams for bis-(1-tert-butyl-3-phenyl-4-bromophenyl-1,2,4-triazol-5-yliden)palladium iodide $9 \mathrm{~b}$ with thermal ellipsoids displayed at $50 \%$ probability. All hydrogen atoms have been removed for clarity.

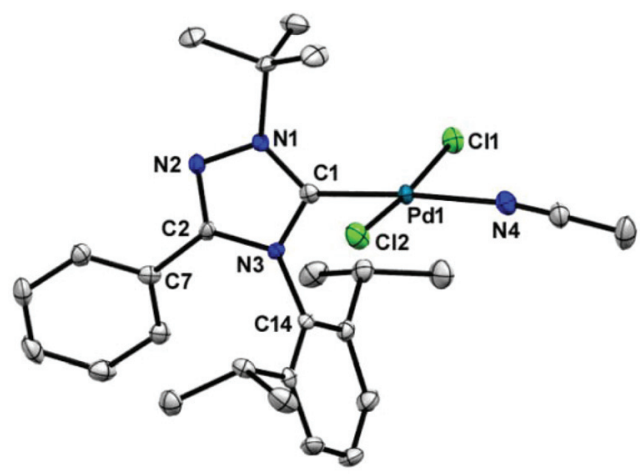

Fig. 6 POV-Ray diagrams for 1-tert-butyl-3-phenyl-4-(2,6-diisopropylphenyl)-1,2,4-triazol-5-yliden)palladium chloride 10a with thermal ellipsoids displayed at $50 \%$ probability. All hydrogen atoms and an acetonitrile molecule have been removed for clarity. 
Table 2 Selected bond lengths and angles for complex 9a

\begin{tabular}{lllll}
\hline & & Bond & & \\
Bond & Length (̊) & order & Angle & $\circ$ \\
\hline $\mathrm{C}(1)-\mathrm{N}(2)$ & $1.338(4)$ & 1.782 & $\mathrm{~N}(1)-\mathrm{C}(1)-\mathrm{N}(2)$ & $103.7(3)$ \\
$\mathrm{C}(1)-\mathrm{N}(1)$ & $1.368(5)$ & 1.609 & $\mathrm{C}(1)-\mathrm{Pd}(1)-\mathrm{Cl}(1)$ & $89.70(10)$ \\
$\mathrm{C}(2)-\mathrm{N}(3)$ & $1.308(5)$ & 1.954 & $\mathrm{Cl}(1)-\mathrm{Pd}(1)-\mathrm{Cl}(1 \mathrm{a})$ & $180.00(5)$ \\
$\mathrm{C}(2)-\mathrm{N}(1)$ & $1.377(4)$ & 1.557 & $\mathrm{~N}(3)-\mathrm{C}(2)-\mathrm{N}(1)-\mathrm{C}(1)$ & $-0.2(4)$ \\
$\mathrm{C}(2)-\mathrm{C}(9)$ & $1.469(5)$ & 1.330 & $\mathrm{~N}(1)-\mathrm{C}(1)-\mathrm{N}(2)-\mathrm{N}(3)$ & $-1.7(4)$ \\
$\mathrm{C}(3)-\mathrm{N}(1)$ & $1.443(4)$ & 1.178 & $\mathrm{~N}(1)-\mathrm{C}(2)-\mathrm{C}(9)-\mathrm{C}(10)$ & $36.3(6)$ \\
$\mathrm{N}(2)-\mathrm{N}(3)$ & $1.386(4)$ & 1.323 & $\mathrm{C}(4)-\mathrm{C}(3)-\mathrm{N}(1)-\mathrm{C}(1)$ & $69.3(5)$ \\
$\mathrm{N}(2)-\mathrm{C}(15)$ & $1.500(5)$ & 0.851 & $\mathrm{Pd}(1)-\mathrm{C}(1)-\mathrm{N}(1)-\mathrm{C}(2)$ & $-174.1(2)$ \\
$\mathrm{C}(6)-\mathrm{Br}(1)$ & $1.895(4)$ & - & $\mathrm{Pd}(1)-\mathrm{C}(1)-\mathrm{N}(2)-\mathrm{C}(15)$ & $-4.4(6)$ \\
$\mathrm{C}(1)-\mathrm{Pd}(1)$ & $2.025(4)$ & - & $\mathrm{N}(1)-\mathrm{C}(1)-\mathrm{Pd}(1)-\mathrm{Cl}(1)$ & $86.0(3)$ \\
$\mathrm{Pd}(1)-\mathrm{Cl}(1)$ & $2.3301(10)$ & - & $\mathrm{N}(2)-\mathrm{C}(1)-\mathrm{Pd}(1)-\mathrm{Cl}(1)$ & $92.4(4)$ \\
& & & &
\end{tabular}

Table 3 Selected bond lengths and angles for complex 9b

\begin{tabular}{lllll}
\hline & & Bond & & \\
Bond & Length (̊) & order & Angle & $\circ$ \\
\hline $\mathrm{C}(1)-\mathrm{N}(2)$ & $1.340(7)$ & 1.770 & $\mathrm{~N}(1)-\mathrm{C}(1)-\mathrm{N}(2)$ & $103.4(4)$ \\
$\mathrm{C}(1)-\mathrm{N}(1)$ & $1.368(7)$ & 1.609 & $\mathrm{C}(1)-\mathrm{Pd}(1)-\mathrm{I}(1)$ & $90.02(15)$ \\
$\mathrm{C}(2)-\mathrm{N}(3)$ & $1.308(7)$ & 1.954 & $\mathrm{I}(2)-\mathrm{Pd}(1)-\mathrm{I}(1)$ & $176.59(2)$ \\
$\mathrm{C}(2)-\mathrm{N}(1)$ & $1.386(7)$ & 1.506 & $\mathrm{~N}(3)-\mathrm{C}(2)-\mathrm{N}(1)-\mathrm{C}(1)$ & $-0.2(6)$ \\
$\mathrm{C}(2)-\mathrm{C}(9)$ & $1.474(7)$ & 1.305 & $\mathrm{~N}(1)-\mathrm{C}(1)-\mathrm{N}(2)-\mathrm{N}(3)$ & $0.8(6)$ \\
$\mathrm{C}(3)-\mathrm{N}(1)$ & $1.435(7)$ & 1.224 & $\mathrm{~N}(1)-\mathrm{C}(2)-\mathrm{C}(9)-\mathrm{C}(10)$ & $12.3(10)$ \\
$\mathrm{N}(2)-\mathrm{N}(3)$ & $1.376(6)$ & 1.374 & $\mathrm{C}(4)-\mathrm{C}(3)-\mathrm{N}(1)-\mathrm{C}(1)$ & $69.3(5)$ \\
$\mathrm{N}(2)-\mathrm{C}(15)$ & $1.491(7)$ & 0.902 & $\mathrm{Pd}(1)-\mathrm{C}(1)-\mathrm{N}(1)-\mathrm{C}(2)$ & $-179.7(4)$ \\
$\mathrm{C}(6)-\mathrm{Br}(1)$ & $1.907(5)$ & - & $\mathrm{Pd}(1)-\mathrm{C}(1)-\mathrm{N}(2)-\mathrm{C}(15)$ & $-6.3(9)$ \\
$\mathrm{C}(1)-\mathrm{Pd}(1)$ & $2.034(5)$ & - & $\mathrm{N}(1)-\mathrm{C}(1)-\mathrm{Pd}(1)-\mathrm{I}(1)$ & $85.8(5)$ \\
$\mathrm{Pd}(1)-\mathrm{I}(1)$ & $2.6014(7)$ & - & $\mathrm{N}(2)-\mathrm{C}(1)-\mathrm{Pd}(1)-\mathrm{I}(1)$ & $-97.6(5)$
\end{tabular}

Table 4 Selected bond lengths and angles for complex 10a

\begin{tabular}{lllll}
\hline & & Bond & & \\
Bond & Length $(\AA)$ & order & Angle & $\circ$ \\
\hline $\mathrm{C}(1)-\mathrm{N}(2)$ & $1.329(4)$ & 1.833 & $\mathrm{~N}(1)-\mathrm{C}(1)-\mathrm{N}(3)$ & $104.6(2)$ \\
$\mathrm{C}(1)-\mathrm{N}(1)$ & $1.366(4)$ & 1.621 & $\mathrm{C}(1)-\mathrm{Pd}(1)-\mathrm{Cl}(1)$ & $92.36(8)$ \\
$\mathrm{C}(2)-\mathrm{N}(3)$ & $1.384(4)$ & 1.517 & $\mathrm{Cl}(1)-\mathrm{Pd}(1)-\mathrm{Cl}(2)$ & $173.88(3)$ \\
$\mathrm{C}(2)-\mathrm{N}(1)$ & $1.309(4)$ & 2.142 & $\mathrm{C}(1)-\mathrm{N}(1)-\mathrm{N}(2)-\mathrm{C}(2)$ & $0.4(3)$ \\
$\mathrm{N}(1)-\mathrm{N}(2)$ & $1.375(3)$ & 1.379 & $\mathrm{~N}(3)-\mathrm{C}(1)-\mathrm{N}(1)-\mathrm{N}(2)$ & $0.1(3)$ \\
$\mathrm{C}(2)-\mathrm{C}(7)$ & $1.482(4)$ & 1.264 & $\mathrm{C}(19)-\mathrm{C}(14)-\mathrm{N}(3)-\mathrm{C}(1)$ & $102.1(3)$ \\
$\mathrm{N}(3)-\mathrm{C}(14)$ & $1.457(4)$ & 1.098 & $\mathrm{~N}(3)-\mathrm{C}(2)-\mathrm{C}(7)-\mathrm{C}(8)$ & $151.0(3)$ \\
$\mathrm{C}(3)-\mathrm{N}(1)$ & $1.514(4)$ & 0.770 & $\mathrm{Pd}(1)-\mathrm{C}(1)-\mathrm{N}(3)-\mathrm{C}(2)$ & $175.50(19)$ \\
$\mathrm{C}(1)-\mathrm{Pd}(1)$ & $1.963(3)$ & - & $\mathrm{Pd}(1)-\mathrm{C}(1)-\mathrm{N}(2)-\mathrm{C}(15)$ & $-6.3(9)$ \\
$\mathrm{Pd}(1)-\mathrm{Cl}(1)$ & $2.3078(8)$ & - & $\mathrm{N}(1)-\mathrm{C}(1)-\mathrm{Pd}(1)-\mathrm{Cl}(1)$ & $-84.3(3)$ \\
$\operatorname{Pd}(1)-\mathrm{N}(4)$ & $2.075(3)$ & - & $\mathrm{N}(1)-\mathrm{C}(1)-\mathrm{Pd}(1)-\mathrm{Cl}(2)$ & $89.6(3)$ \\
& & & &
\end{tabular}

(1.799).$^{10}$ For comparison, similar features were observed for the linear bistriazolylidene complexes of copper(I) chloride $^{9,16}$ and the related bistriazolylidene chelate complex of copper(I) iodide. $^{11}$

The dihedral angles of the aromatic rings in molecules $\mathbf{9 a}, \mathbf{b}$ are also close to that of the initial carbene. The C(2)-nucleus is twisted relative to the triazole ring by $36.3^{\circ}(\mathbf{9 a})$ and $12.3^{\circ}(\mathbf{9 b})$, respectively versus $29.9^{\circ}$ for the initial carbene.

Furthermore, the N(1) nucleus is twisted with respect to the same plane by $69.3^{\circ}(\mathbf{9 a}, \mathbf{b})$ versus $51.1^{\circ}$ for the initial carbene. The bond orders for $\mathrm{C}(2)-\mathrm{C}(9)$ and $\mathrm{N} 1-\mathrm{C}(3)$ are $1.31-1.33$ and $1.18-1.22$, respectively, since the $\mathrm{C}(2)$ nucleus is naturally more conjugated with the triazole ring than with the $\mathrm{N}(1)$-nucleus.
The bond angles at the carbenoid carbon atom $\left(103^{\circ}\right)$ are significantly larger than those for the carbene $\left(100.3^{\circ}\right)$ and are noticeably smaller than that observed for the salt complex $\left(110^{\circ}\right){ }^{7,34}$ Furthermore, the Pd-C bond distances (2.025, $2.034 \AA$ ) are notably larger than the sum of the covalent radii for these atoms $(1.95 \AA)$ and significantly larger than the sum of covalent radius of the carbon atom and the ionic radius of palladium(II) (1.75 $\AA$ ) that is indicative of a C-Pd coordination bond in these complexes.

The Pd-Cl bond distances in complex $9 a(2.330 \AA)$ are intermediate in length between those of covalent and ionic bonds (the sum of the covalent radii is $2.19 \AA$, while the sum of the ionic radii is $2.67 \AA$ ). Overall, however it is closer to a covalent bond (the extent of $\operatorname{Pd}(1)-\mathrm{Cl}(1)$ ionization is approximately $29 \%)$. In the case of complex $9 \mathbf{b}$, the Pd-I bond (2.60 $⿱$ ) is also intermediate in character with respect to covalency $v s$. ionicity (the sum of the covalent radii is $2.53 \AA$ and the sum of the ionic radii is $3.06 \AA$ ). Overall, however the Pd-I bond more closely resembles a covalent bond (the extent of $\operatorname{Pd}(1)-\mathrm{I}(1)$ ionization is 13\%). Thus, complexes 9a,b possess typical structures with C-Pd coordination bonds and shortened Pd-halogen bonds.

Compound 10a is a monocarbene-acetonitrile palladium complex. The bond order of the $\mathrm{N}(1)-\mathrm{C}(1)$ bond in this molecule ( $p 1.833)$ is larger than that of the initial carbene (1.718). The Pd-C bond distance (1.963 $\AA$ ) is close to the sum of the covalent radii of the constituent atoms $(1.95 \AA)$ and significantly larger than the sum of the covalent radius of the carbon atom and the ionic radius of palladium(II) (1.75 $)$ ). The latter observation, along with the bond orders, indicates that there is a stronger interaction between the carbene carbon and the palladium atoms than in the case of the biscarbene complexes 9a,b. Moreover, the $\mathrm{Pd}-\mathrm{Cl}$ bond in the structure of 10a $(2.308 \AA)$ is intermediate in length between covalent and ionic bonds (the sum of the covalent radii is $2.19 \AA$ and the sum of the ionic radii is $2.67 \AA$ ), but closer to that of a covalent bond (the extent of $\mathrm{Pd}(1)-\mathrm{Cl}(1)$ ionization is approximately $25 \%$ ).

The bond angle of the carbenoid carbon atom $\left(103.4^{\circ}\right)$ is significantly larger than that of the initial carbene $\left(100.5^{\circ}\right)$ however the salt carbenoid angle is larger by comparison $\left(110^{\circ}\right) .^{7,34}$ Furthermore, the $\mathrm{C}(2)$ nucleus is twisted relative to that of the triazole ring by $151.0^{\circ}$ as opposed to $29.9^{\circ}$ for the initial carbene. Furthermore, the N(3)-nucleus is twisted with respect to the triazole ring by $102.1^{\circ}$ versus $51.1^{\circ}$ for the same carbene. The bond orders for $\mathrm{C}(2)-\mathrm{C}(7)$ and $\mathrm{N}(3)-\mathrm{C}(14)$ are 1.264 and 1.098, respectively. Thus, complex 10a adopts a typical structure with a strong C-Pd coordination bond and a shortened bond $\mathrm{Pd}-\mathrm{Cl}$.

\section{Catalytic tests}

Test reactions for the hydrodechlorination catalysis were carried out by heating a reaction mixture of the haloarene with potassium or sodium isopropoxides, which had been generated from potassium or sodium tert-butoxide or hydroxide, in the presence of a catalyst in isopropanol at $80^{\circ} \mathrm{C}$. Control of the conversion (on 1 chlorine atom) was calculated according to the masses of the sodium or potassium chlorides, both of 
Table 5 Catalytic efficiencies of carbene complexes $9 a-d, \mathbf{1 0 a}-d, 5$ for the reaction of $p$-dichlorobenzene with potassium tert-butoxide in isopropanol at $80^{\circ} \mathrm{C}$

\begin{tabular}{llcrrr}
\hline Catalyst & $\begin{array}{l}\text { Catalyst amount } \\
(\mathrm{mol} \%)\end{array}$ & $\begin{array}{l}\text { Reaction } \\
\text { time }(\mathrm{h})\end{array}$ & $\begin{array}{l}\text { Conv. } \\
(\%)\end{array}$ & $\begin{array}{l}\text { TON per } \\
1 \mathrm{Cl}\end{array}$ & $\begin{array}{r}\text { TOF } \\
\left(\mathrm{h}^{-1}\right)\end{array}$ \\
\hline $\mathbf{9 a}$ & 0.1 & 8 & 25 & 500 & 62 \\
$\mathbf{9 b}$ & 0.1 & 8 & 11 & 220 & 28 \\
$\mathbf{9 c}$ & 0.1 & 8 & 70 & 1400 & 175 \\
$\mathbf{9 d}$ & 0.1 & 8 & 38 & 760 & 95 \\
$\mathbf{1 0 a}$ & 0.1 & 8 & 66 & 1320 & 165 \\
$\mathbf{1 0 b}$ & 0.1 & 8 & 58 & 1160 & 145 \\
$\mathbf{1 0 c}$ & 0.1 & 8 & 72 & 1140 & 180 \\
$\mathbf{1 0 c}$ & 0.01 & 24 & 40 & 8000 & 334 \\
$\mathbf{1 0 d}$ & 0.01 & 24 & 100 & 20000 & 840 \\
$\mathbf{5}$ & 0.01 & 8 & 63 & 12600 & 1560 \\
$\mathbf{5}$ & 0.01 & 24 & 88 & 17600 & 734
\end{tabular}

${ }^{a}$ The reagent is potassium tert-butoxide to which $1 \mathrm{~mol} \%$ lithium tertbutoxide has been added.

Table 6 Catalytic efficiencies of carbene complexes 9d, 10b,c, 5 for the reaction of $p$-dichlorobenzene with sodium tert-butoxide in isopropanol at $80^{\circ} \mathrm{C}$

\begin{tabular}{llllrr}
\hline Catalyst & $\begin{array}{l}\text { Catalyst amount } \\
(\mathrm{mol} \%)\end{array}$ & $\begin{array}{l}\text { Reaction } \\
\text { time }(\mathrm{h})\end{array}$ & $\begin{array}{l}\text { Conv. } \\
(\%)\end{array}$ & $\begin{array}{l}\text { TON per } \\
1 \mathrm{Cl}\end{array}$ & $\begin{array}{r}\text { TOF } \\
\left(\mathrm{h}^{-1}\right)\end{array}$ \\
\hline 9d & 0.01 & 24 & 53 & 10600 & 440 \\
10b & 0.01 & 24 & 36 & 7200 & 300 \\
10c & 0.01 & 6 & 77 & 15400 & 2230 \\
$\mathbf{5}$ & 0.01 & 24 & 32 & 6400 & 266
\end{tabular}

Table 7 Catalytic efficiencies of carbene complexes $9 d, 10 a-d$ for the reaction of $p$-dichlorobenzene with sodium hydroxide in isopropanol at $80^{\circ} \mathrm{C}$

\begin{tabular}{llllll}
\hline Catalyst & $\begin{array}{l}\text { Catalyst amount } \\
(\mathrm{mol} \%)\end{array}$ & $\begin{array}{l}\text { Reaction } \\
\text { time }(\mathrm{h})\end{array}$ & $\begin{array}{l}\text { Conv. } \\
(\%)\end{array}$ & $\begin{array}{l}\text { TON per } \\
1 \mathrm{Cl}\end{array}$ & $\begin{array}{l}\text { TOF } \\
\left(\mathrm{h}^{-1}\right)\end{array}$ \\
\hline $\mathbf{1 0 c}$ & 0.1 & 8 & 100 & 2000 & 250 \\
$\mathbf{1 0 c}$ & 0.01 & 24 & 34 & 6800 & 284 \\
$\mathbf{1 0 d}$ & 0.01 & 24 & 21 & 4200 & 176 \\
$\mathbf{5}$ & 0.01 & 24 & 96 & 19200 & 800 \\
\hline
\end{tabular}

which are insoluble in isopropanol. The most efficient catalysis trials were examined on the basis of gas chromatography. The catalytic efficiencies were estimated using the values of TON and TOF.

A summary of the results pertaining to the studies of the catalytic efficiencies for the carbene complexes $\mathbf{5}, \mathbf{9 a}-\mathbf{d}$, and 10a-d with respect to the model compound $p$-dichlorobenzene and a variety of bases is presented in Tables $5-7$.

Examination of Table 5 reveals that the hydrodehalogenation of $p$-dichlorobenzene with potassium tert-butoxide proceeds efficiently with the majority of the carbene catalyst complexes that were tested. The most rapid reaction was observed with the triazolylidene monocarbene complex 10d (after $24 \mathrm{~h}$ of the reaction the maximum TON and TOF values reached 20000 and $840 \mathrm{~h}^{-1}$ respectively). The efficiency of complex 10c is relatively low (TON 1140 cycles after $8 \mathrm{~h}$ ), however, in the presence of $1 \mathrm{~mol} \%$ lithium tert-butoxide the TON is enhanced up to 8000 cycles after $24 \mathrm{~h}$.

When sodium tert-butoxide was used for these hydrodehalogenation reactions (Table 6), a significant increase in the efficiency indices by almost an order of magnitude was observed for the triazolylidene complexes 9d, 10b,c (TON 7200-15 400, TOF $300-2230 \mathrm{~h}^{-1}$ ). In fact, these values exceeded those for the etalon complex 5 (TON 6400, TOF $266 \mathrm{~h}^{-1}$ ).

The hydrodechlorination reaction was examined in the presence of sodium hydroxide and isopropanol using complexes $\mathbf{5}$ and 10c,d. The use of sodium hydroxide is particularly appropriate in view of the possible development of a technology for haloarene (production wastes) neutralization (detoxification) since it is an inexpensive reagent. It was found (Table 7) that the triazolylidene complexes 10c,d exhibited high efficiencies for the reaction of $p$-dichlorobenzene with sodium hydroxide (TON 2000-6800, TOF 176-284 $\mathrm{h}^{-1}$ ). However, for 10d this represents threefold decrease with respect to the use of potassium tert-butoxide.

Interestingly, the known complex $\mathbf{5}$ appeared to be somewhat more effective for the reaction with sodium hydroxide (TON 19 200, TOF $800 \mathrm{~h}^{-1}$ ), than those with potassium tert-butoxide (TON 17600 , TOF $734 \mathrm{~h}^{-1}$ ) and sodium tert-butoxide (TON 6400, TOF $266 \mathrm{~h}^{-1}$ ).

On the basis of gas chromatographic data, noticeable quantities of haloarenes were not observed in the experiments that resulted in quantitative conversion of the initial haloarene.

In conclusion, the highest efficiency is apparent for the catalysts that feature the sterically bulky 1-(1-adamantyl)-3-phenyl4-(2,6-diisopropylphenyl)-1,2,4-triazol-5-ylidene ligand.

The high TON of 20000 cycles (10d) with potassium tertbutoxide and TON 15400 with sodium tert-butoxide exceed the efficiency level of complex 5 (TON 17600 and 6400, respectively). Another factor that contributes to the catalytic efficiency is the presence of iodide as the second ligand which raises the efficiency of the catalyst (TON 20000 cycles for 10d, TON 8000 cycles for 10c).

As far as we know, the mechanism of haloarene (i.e. $p$-dichlorobenzene) hydrodehalogenation ${ }^{2,3}$ involves the formation of palladium(0) complex (D) as the first step via the interaction of the palladium(II) complex with metal isopropoxide, followed by reaction with the haloarene $\mathbf{E}$ thereby affording the palladium(II) species (F) (Scheme 2).

The activated complex $\mathbf{F}$ reacts subsequently with the metal isopropoxide via the nucleophilic substitution of the halogen, thus forming the adduct of the $\mathrm{H}$-arene with palladium species $\mathbf{H}$ due to decomposition of the previously formed isopropoxide complex G. Finally, decomposition of the latter produces H-arene I and the palladium(0) complex D. The enthalpy changes that take place during chlorobenzene conversion catalyzed by complex 10a were evaluated on the basis of DFT, B3LYP5, 3-21G calculations (Scheme 2, in $\mathrm{kcal} \mathrm{mol}^{-1}$ ). These calculations indicate that a strong exothermic reaction takes place between palladium(0) compound $\mathbf{D}$ and chlorobenzene 


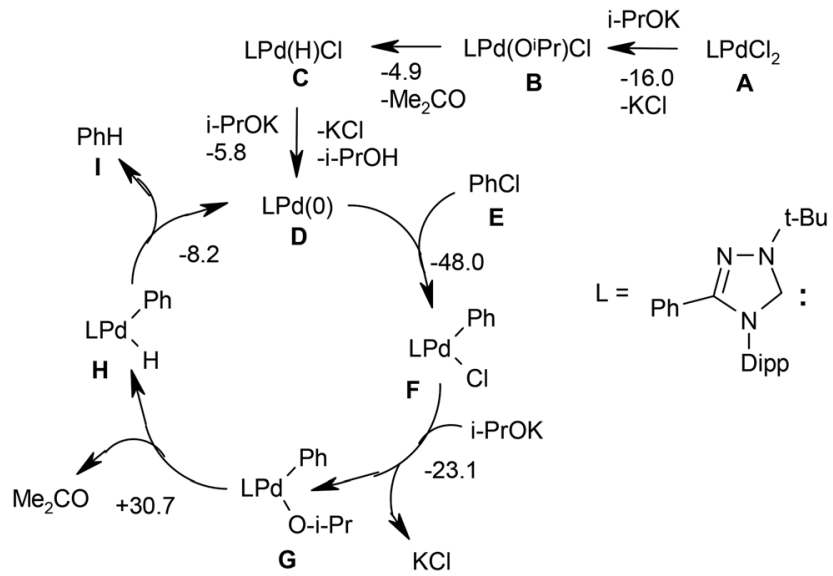

Scheme 2 Mechanism of haloarene hydrodehalogenation.

$\left(\Delta H-48.0 \mathrm{kcal} \mathrm{mol}^{-1}\right)$ and that the conversion of compound $\mathbf{G}$ to $\mathbf{H}$ is endothermic $\left(\Delta H+30.7 \mathrm{kcal} \mathrm{mol}^{-1}\right)$. An important stage in the foregoing process may be the interaction of the initial precatalyst A with the metal isopropoxide $(\Delta H-16.0 \mathrm{kcal}$ $\mathrm{mol}^{-1}$ ), which is the initial stage in the formation of these molecular complexes. As might be expected, the stabilities of these complexes depend on steric protection of the palladium complex.

A possible reason for the increase in catalytic efficiency for sterically shielded carbene complexes, particularly 10c,d, is attributed to the steric protection which results in an increased stability of the intermediate $\operatorname{Pd}(0)$ species in the reaction medium.

\section{Conclusions}

Along with the syntheses of the new biscarbene palladium complexes 9a,b from the known carbene 8a, a series of sterically shielded 1,3,4-trisubstituted 1,2,4-triazol-5-ylidenes $\mathbf{8 b}$-d and their palladium complexes $\mathbf{9 c}, \mathbf{d}, \mathbf{1 0 a}-\mathbf{d}$ have been synthesized in the present work. It was found that sterically shielded compounds $(\mathbf{9 c}, \mathbf{d}, \mathbf{1 0 a}-\mathbf{d})$ are effective catalysts for $p$-dichlorobenzene hydrodechlorination. The efficiencies for the monocarbene complexes $\mathbf{1 0 c}, \mathbf{d}$ were shown to be somewhat higher than those for the biscarbene complexes 9c,d. However, the latter results are strongly dependent on the nature of the reagent.

\section{Experimental section}

\section{General}

${ }^{1} \mathrm{H}$ NMR and ${ }^{13} \mathrm{C}$ NMR spectra were recorded using a Bruker Avance II 400 spectrometer (400 MHz for ${ }^{1} \mathrm{H}$ NMR spectra and $100 \mathrm{MHz}$ for ${ }^{13} \mathrm{C}$ NMR spectra) in DMSO- $\mathrm{d}_{6}, \mathrm{C}_{6} \mathrm{D}_{6}$ or $\mathrm{CDCl}_{3}$ solution or in the solid state. The ${ }^{1} \mathrm{H}$ NMR and ${ }^{13} \mathrm{C}$ NMR chemical shifts are reported relative to tetramethylsilane (TMS) (solution) and sodium 2,2-dimethyl-2-silapentan-5-sulfonate (DSS) (solid state). The X-ray diffraction data were collected using a Rigaku AFC12 Saturn 724+ CCD diffractometer equipped with a Rigaku XStream low temperature device that is operated at $100 \mathrm{~K}$, a Rigaku SCX-Mini Diffractometer equipped with a Rigaku XStream low temperature device that is operated at $100 \mathrm{~K}$, or a Nonius-Kappa CCD diffractometer with an Oxford cryostream 600 that is operated at $153 \mathrm{~K}$. All instruments used a graphite-monochromated Mo Ko radiation source $(\lambda=0.71075 \AA)$. Corrections were applied for Lorentz and polarization effects. The structures were solved by direct methods and refined by full-matrix least-squares cycles on $F^{2}$ using the Siemens SHELXTL PLUS 5.0 (PC) software package ${ }^{35}$ and PLATON. ${ }^{36}$ All non-hydrogen atoms were refined anisotropically. The hydrogen atoms were placed in fixed, calculated positions using a riding model.

Thin-layer chromatography was performed on silica gel with chloroform or a 10:1 mixture of chloroform and methanol as the eluent, followed by development with iodine. Elemental analyses were carried out at the Analytical Laboratory of the Litvinenko Institute of Physical Organic and Coal Chemistry. The quantum chemical calculations were performed with the help of Firefly 8.0 program.

\section{3,4-Diaryl-1,2,4-triazoles (6b,c) (general procedure)}

3,4-Diaryl-1,2,4-triazoles were obtained according to the modified procedure of the work ${ }^{37}$ by the ring transformation of 2-phenyl-1,3,4-oxadiazole with the respective anilines in the presence of trifluoroacetic acid at $190^{\circ} \mathrm{C}$. The mixture of aromatic amine $(20 \mathrm{mmol})$ and trifluoroacetic acid $(20 \mathrm{mmol})$ in $o$-dichlorobenzene (1-2 mL) was added to 2-phenyl-1,3,4-oxadiazole $(20 \mathrm{mmol})$ and heated at $190{ }^{\circ} \mathrm{C}$ for $12 \mathrm{~h}$. The resulting oil or crystalline product was washed 5-6 times with petroleum ether $(50 \mathrm{ml})$. Then $10 \%$ aqueous solution of potassium hydroxide was added and the mixture was stirred for 15-20 min. The resulting crystalline precipitate was filtered off, washed with water, then with a mixture of petroleum ether-isopropanol $(3: 1)$ and petroleum ether and dried. The obtained products were recrystallized from benzene.

\section{3-Phenyl-4-(2,4,6-trimethylphenyl)-1,2,4-triazole (6b)}

Yield $2.63 \mathrm{~g}, 50 \%, \mathrm{mp} 125-126{ }^{\circ} \mathrm{C}$ (benzene). $\delta_{\mathrm{H}}(400 \mathrm{MHz}$; $\left.\mathrm{CDCl}_{3} ; \mathrm{Me}_{4} \mathrm{Si}\right): 1.86\left(\mathrm{~s}, 6 \mathrm{H}, o-\mathrm{CH}_{3} \mathrm{C}\right), 2.31\left(\mathrm{~s}, 3 \mathrm{H}, p-\mathrm{CH}_{3} \mathrm{C}\right), 7.09 \mathrm{~s}$ $(2 \mathrm{H}, \mathrm{Ar}), 7.39 \mathrm{~s}(5 \mathrm{H}, \mathrm{Ar}), 8.73 \mathrm{~s}\left(1 \mathrm{H}, \mathrm{C}^{5} \mathrm{HN}\right)$. Compound $\mathbf{6 b}$ was identical to the product of the same reaction in ionic liquids isolated by column chromatography ${ }^{33}\left(\mathrm{mp} 125-126^{\circ} \mathrm{C}\right)$.

\section{3-Phenyl-4-(2,6-diisopropylphenyl)-1,2,4-triazole (6c)}

Yield $3.05 \mathrm{~g}, 50 \%$, mp $98-100{ }^{\circ} \mathrm{C}$ (benzene). Found: C, 78.7; H, 7.4; N, 13.9. Calc. for $\mathrm{C}_{20} \mathrm{H}_{23} \mathrm{~N}_{3}: \mathrm{C}, 78.7 ; \mathrm{H}, 7.6 ; \mathrm{N}, 13.8 \%$. $\delta_{\mathrm{H}}$ (400 MHz; DMSO-d $\left.{ }_{6} ; \mathrm{Me}_{4} \mathrm{Si}\right): 0.88$ (d, 6H, $\mathrm{CH}_{3} \mathrm{C}, J 6.8 \mathrm{~Hz}$ ), 1.09 (d, $6 \mathrm{H}, \mathrm{CH}_{3} \mathrm{C}, J 6.8 \mathrm{~Hz}$ ), 2.24 (qr, $2 \mathrm{H}, \mathrm{CHC}, J 6.8 \mathrm{~Hz}$ ), 7.25-7.42 $(\mathrm{m}, 7 \mathrm{H}, \mathrm{Ar}), 7.58(\mathrm{~m}, 1 \mathrm{H}, \mathrm{Ar}), 8.88\left(\mathrm{~s}, 1 \mathrm{H}, \mathrm{C}^{5} \mathrm{HN}\right) . \delta_{\mathrm{H}}(400 \mathrm{MHz}$; $\left.\mathrm{CDCl}_{3} ; \mathrm{Me}_{4} \mathrm{Si}\right): 1$ form: $0.90\left(\mathrm{~d}, 6 \mathrm{H}, \mathrm{CH}_{3} \mathrm{C}, J 6.8 \mathrm{~Hz}\right), 1.10(\mathrm{~d}$, $6 \mathrm{H}, \mathrm{CH}_{3} \mathrm{C}, J 6.8 \mathrm{~Hz}$ ), 2.37 (qr, $\left.2 \mathrm{H}, \mathrm{CHC}, J 6.8 \mathrm{~Hz}\right)(i-\mathrm{Pr}), 8.10$ (s, $\left.1 \mathrm{H}, \mathrm{C}^{5} \mathrm{HN}\right) ; 2$ form: $1.19\left(\mathrm{~d}, 12 \mathrm{H}, \mathrm{CH}_{3} \mathrm{C}\right), 3.02(\mathrm{qr}, 2 \mathrm{H}, \mathrm{CHC}$, $J 6.8 \mathrm{~Hz})(i-\mathrm{Pr}) ; 8.30\left(\mathrm{~s}, 1 \mathrm{H}, \mathrm{C}^{5} \mathrm{HN}\right)$; general for both forms: 7.20-7.37 (m, 12H, Ar), $7.45(\mathrm{~d}, 3 \mathrm{H}, \mathrm{Ar}, J 7.6 \mathrm{~Hz}), 7.51(\mathrm{dd}, 1 \mathrm{H}$, 
Ar, $J 7.6 \mathrm{~Hz}$ ). The first form of compound $6 \mathrm{c}$ was identical to the product of the same reaction in ionic liquids isolated by column chromatography ${ }^{33}$ (mp 114-115 $\left.{ }^{\circ} \mathrm{C}\right)$.

\section{1-Alkyl-3,4-diaryl-1,2,4-triazolium perchlorates (7b-d) (general procedure)}

The mixture of sodium iodide $(50-60 \mathrm{mmol})$ and 1.5 -fold access of tert-butyl chloride in acetic acid $(10 \mathrm{~mL})$ was boiled for $1.5 \mathrm{~h}$. One equivalent (to iodide amount) of the respective 3,4-diaryl-1,2,4-triazole 6a,c was added and boiled for $21 \mathrm{~h}$. Then water $(20 \mathrm{~mL})$ and sodium sulfite were added to the obtained mixture to discolor the solution. The mixture was diluted by water $(0.5 \mathrm{~L})$ and activated carbon (1-3 g) was added. The subsequent mixture was heated to boiling and filtered hot. Sodium perchlorate was added in an amount exceeding equivalence by $10-20 \%$. The precipitate that formed was filtered off, washed with isopropanol and ether, recrystallized from the respective solvent, and subsequently dried. The salts 7b,d were obtained similarly using 1-bromoadamantane instead of tert-butyl iodide. The heating time was 10-18 h.

\section{1-(1-Adamantyl)-3-phenyl-4-(2,4,6-trimethylphenyl)-1,2,4- triazolium perchlorate $(7 \mathrm{~b})$}

The heating time was $10 \mathrm{~h}$. Yield $85 \%, \mathrm{mp}>300{ }^{\circ} \mathrm{C}$ (acetic acid). Found: $\mathrm{C}, 65.0 ; \mathrm{H}, 6.5 ; \mathrm{Cl}, 7.1 ; \mathrm{N}, 8.5$. Calc. for $\mathrm{C}_{27} \mathrm{H}_{32} \mathrm{ClN}_{3} \mathrm{O}_{4}$ : C, 65.1; H, 6.5; Cl, 7.1; N, 8.4\%. $\delta_{\mathrm{H}}(400 \mathrm{MHz}$; $\mathrm{CDCl}_{3} ; \mathrm{Me}_{4} \mathrm{Si}$ ): 1.79 (s, 6H, Ad), 2.02 (s, 6H, $\left.\mathrm{CH}_{3} \mathrm{C}\right), 2.30$ (s, 3H, $\mathrm{Ad}), 2.35$ (s, 3H, $p-\mathrm{CH}_{3} \mathrm{C}$ ), 2.36 (s, 6H, $\left.o-\mathrm{CH}_{3} \mathrm{C}\right), 7.19$ (s, 2H, $\mathrm{Ar}$ ), 7.44 (dd, 2H, Ar, J 7.6 Hz), 7.51 (dd, 2H, Ar, J 8.0 Hz), 7.62 (dd, $1 \mathrm{H}, \mathrm{Ar}, J 7.2 \mathrm{~Hz}$ ), 10.59 (s, 1H, $\left.\mathrm{C}^{5} \mathrm{HN}\right)$.

\section{1-tert-Butyl-3-phenyl-4-(2,6-diisopropylphenyl)-1,2,4-triazolium} perchlorate $(7 \mathrm{c})$

Yield 64\%, mp 232-234 ${ }^{\circ} \mathrm{C}$ (acetic acid-water, 1:1). Found: C, 62.5; H, 6.9; Cl, 7.6; N, 9.2. Calc. for $\mathrm{C}_{24} \mathrm{H}_{32} \mathrm{ClN}_{3} \mathrm{O}_{4}$ : C, 62.4; $\mathrm{H}, 7.0 ; \mathrm{Cl}, 7.7 ; \mathrm{N}, 9.1 \%$. $\delta_{\mathrm{H}}\left(400 \mathrm{MHz} ; \mathrm{DMSO}_{6} \mathrm{~d}_{6} \mathrm{Me}_{4} \mathrm{Si}\right): 0.91$ (d, 6H, J $6.8 \mathrm{~Hz}), 1.16$ (d, 6H, $6.8 \mathrm{~Hz})\left(\mathrm{CH}_{3} \mathrm{C}, i-\mathrm{Pr}\right), 1.81$ (s, 9H, $\mathrm{CH}_{3} \mathrm{C}, t-\mathrm{Bu}$ ), 2.40 (qr, 2H, CHC, $i$-Pr, $J 6.8 \mathrm{~Hz}$ ), 7.44 (d, 2H, $7.6 \mathrm{~Hz}$ ), 7.51 (d, 2H, J 7.6 Hz), 7.54 (d, 2H, J 7.6 Hz), 7.63 (dd, $1 \mathrm{H}, J 7.6 \mathrm{~Hz}$ ), 7.73 (dd, 1H, J 7.6 Hz) (Ar), 10.91 (s, 1H, C $\left.{ }^{5} \mathrm{HN}\right)$.

1-(1-Adamantyl)-3-phenyl-4-(2,6-diisopropylphenyl)-1,2,4triazolium perchlorate $(7 \mathrm{~d})$

The heating time was $18 \mathrm{~h}$. Yield 59\%, mp 210-212 ${ }^{\circ} \mathrm{C}$ (acetic acid-water, $1: 1$ ). Found: C, 66.8; H, 7.0; Cl, 6.6; N, 7.7. Calc. for $\mathrm{C}_{30} \mathrm{H}_{38} \mathrm{ClN}_{3} \mathrm{O}_{4}: \mathrm{C}, 66.7 ; \mathrm{H}, 7.1 ; \mathrm{Cl}, 6.7 ; \mathrm{N}, 7.8 \%$. $\delta_{\mathrm{H}}$ (400 MHz; $\left.\mathrm{CDCl}_{3} ; \mathrm{Me}_{4} \mathrm{Si}\right): 0.91$ (d, 6H, J $\left.4.4 \mathrm{~Hz}\right), 1.28$ (d, 6H, $J 4.4 \mathrm{~Hz}$ ) ( $\mathrm{CH}_{3} \mathrm{C}, i$-Pr), 1.87 (m, 6H, Ad), 2.23 (qr, 2H, CHC, $i$-Pr, $J 4.4 \mathrm{~Hz}), 2.42 \mathrm{~s}$ (3H, Ad), 2.48 (s, 6H, Ad), 7.37 (m, 4H), 7.42 $(\mathrm{m}, 2 \mathrm{H}), 7.51(\mathrm{~m}, 1 \mathrm{H}), 7.63(\mathrm{~m}, 1 \mathrm{H})(\mathrm{Ar}), 10.28\left(\mathrm{~s}, 1 \mathrm{H}, \mathrm{C}^{5} \mathrm{HN}\right)$.

\section{1-Alkyl-3,4-diaryl-1,2,4-triazol-5-ylidenes (8b-d) (general procedure)}

A suspension of 1-tert-butyl-3,4-diaryl-1,2,4-triazolium perchlorate $7 \mathbf{a}-\mathbf{d}$ and potassium tert-butoxide (95\% from the calculated amount) was added to the mixture of anhydrous isopropanol and toluene $(1: 3)$ or in THF and stirred for $1.5 \mathrm{~h}$. The solvent was evaporated and the oil was obtained. This oil was then stirred with petroleum ether and the subsequent precipitate that was formed was filtered off and dried. Then, anhydrous toluene (10-20 mL) was added to the precipitate and stirred for $1 \mathrm{~h}$. The resulting inorganic salt was filtered off. The mother liquor was evaporated and the resulting product was crystallized by stirring with petroleum ether. The precipitate was filtered off, washed several times with petroleum ether, dried, and recrystallized from toluene.

\section{1-(1-Adamantyl)-3-phenyl-4-(2,4,6-trimethylphenyl)-1,2,4- triazol-5-ylidene (8b)}

Yield 50\%, mp 168-169 ${ }^{\circ} \mathrm{C}$ (toluene). Found: C, 81.7; H, 7.8; $\mathrm{N}, 10.5 \%$. Calc. for $\mathrm{C}_{27} \mathrm{H}_{31} \mathrm{~N}_{3}: \mathrm{C}, 81.6 ; \mathrm{H}, 7.9 ; \mathrm{N}, 10.6 \% . \delta_{\mathrm{H}}$ (400 MHz; $\left.\mathrm{C}_{6} \mathrm{D}_{6} ; \mathrm{Me}_{4} \mathrm{Si}\right): 1.64$ (m, 3H, Ad), 1.73 (m, 3H, Ad), $1.97\left(\mathrm{~s}, 6 \mathrm{H}, o-\mathrm{CH}_{3} \mathrm{C}\right), 2.06\left(\mathrm{~s}, 3 \mathrm{H}, p-\mathrm{CH}_{3} \mathrm{C}\right), 2.13(\mathrm{~m}, 3 \mathrm{H}, \mathrm{Ad})$, 2.66 (m, 6H, Ad), 6.69 (s, 2H, Ar), 6.94 (s, 3H, Ar), 7.61 (d, 2H, $\mathrm{Ar}, J 3.6 \mathrm{~Hz}) . \delta_{\mathrm{C}}\left(100 \mathrm{MHz}, \mathrm{C}_{6} \mathrm{D}_{6}, \mathrm{Me}_{4} \mathrm{Si}\right): 18.3\left(o-C \mathrm{H}_{3} \mathrm{C}\right), 21.0$ $\left(p-\mathrm{CH}_{3} \mathrm{C}\right), 30.2$ (CHC, Ad), $36.7\left(\mathrm{CH}_{2} \mathrm{C}, \mathrm{Ad}\right), 44.2\left(\mathrm{CH}_{2} \mathrm{C}, \mathrm{Ad}\right)$, 59.4 (ipso-C, $t$-Bu), 127.7, 128.4, 128.6, 129.5, 130.2 (Ar), 135.5, 136.8, 137.9 (ipso-C, $\mathrm{Ar}$ ), $151.1\left(\mathrm{C}^{3}\right), 211.5\left(\mathrm{C}^{5}\right)$.

\section{1-tert-Butyl-3-phenyl-4-(2,6-diisopropylphenyl)-1,2,4-triazol- 5-ylidene (8c)}

Yield 70\%, mp 112-114 ${ }^{\circ} \mathrm{C}$ (toluene). Found: C, 79.8; H, 8.5; N, 11.7. Calc. for $\mathrm{C}_{24} \mathrm{H}_{31} \mathrm{~N}_{3}: \mathrm{C}, 79.7 ; \mathrm{H}, 8.6 ; \mathrm{N}, 11.6 \%$. $\delta_{\mathrm{H}}$ (400 MHz; $\mathrm{C}_{6} \mathrm{D}_{6} ; \mathrm{Me}_{4} \mathrm{Si}$ ): 0.85 (d, 6H, J 7.2 Hz), 1.18 (d, 6H, $J 7.2 \mathrm{~Hz})\left(\mathrm{CH}_{3} \mathrm{C}, i\right.$-Pr), $1.83\left(\mathrm{~s}, 9 \mathrm{H}, \mathrm{CH}_{3} \mathrm{C}, t\right.$-Bu), 2.74 (qr, $2 \mathrm{H}, J$ $7.2 \mathrm{~Hz}, \mathrm{CHC}, i$-Pr), $6.90(\mathrm{~m}, 3 \mathrm{H}), 7.10$ (d, 2H, J 7.6 Hz), 7.24 $(\mathrm{dd}, 1 \mathrm{H}, J 7.6 \mathrm{~Hz}), 7.61(\mathrm{~m}, 2 \mathrm{H})(\mathrm{Ar}) . \delta_{\mathrm{C}}\left(100 \mathrm{MHz} ; \mathrm{C}_{6} \mathrm{D}_{6}\right.$; $\left.\mathrm{Me}_{4} \mathrm{Si}\right)$ : 22.5, $24.5\left(\mathrm{CH}_{3} \mathrm{C}, i\right.$-Pr), 29.0 (CH, $i$-Pr), $30.9\left(\mathrm{CH}_{3} \mathrm{C}, t\right.$ $\mathrm{Bu}$ ), 59.3 (ipso-C, $t$-Bu), 128.2, 128.5, 129.5, 129.6 (Ar), 124.2, 136.6, 146.1 (ipso-C, $\mathrm{Ar}$ ), $151.8\left(\mathrm{C}^{3}\right), 213.0\left(\mathrm{C}^{5}\right)$.

\section{1-(1-Adamantyl)-3-phenyl-4-(2,6-diisopropylphenyl)-1,2,4- triazol-5-ylidene (8d)}

Yield 68\%, mp 151-153 ${ }^{\circ} \mathrm{C}$ (toluene). Found: C, 82.1; H, 8.4; N, 9.6. Calc. for $\mathrm{C}_{30} \mathrm{H}_{37} \mathrm{~N}_{3}$ : C, 82.0; H, 8.5; N, 9.6\%. $\delta_{\mathrm{H}}(400 \mathrm{MHz}$; $\left.\mathrm{C}_{6} \mathrm{D}_{6} ; \mathrm{Me}_{4} \mathrm{Si}\right): 0.87(\mathrm{~d}, 6 \mathrm{H}, J 6.8 \mathrm{~Hz}), 1.20(\mathrm{~d}, 6 \mathrm{H}, J 6.8 \mathrm{~Hz})$ $\left(\mathrm{CH}_{3} \mathrm{C}, i-\mathrm{Pr}\right), 1.64(\mathrm{~m}, 3 \mathrm{H}), 1.71(\mathrm{~m}, 3 \mathrm{H}), 2.12(\mathrm{~m}, 3 \mathrm{H}), 2.63(\mathrm{~m}$, 6H) (Ad), 2.76 (qr, 2H, CHC, $i$-Pr, $J 6.8 \mathrm{~Hz}), 6.94$ (m, 3H), 7.12 (d $2 \mathrm{H}, J 7.6 \mathrm{~Hz}), 7.26$ (dd, 1H, J $7.6 \mathrm{~Hz}), 7.62(\mathrm{~m}, 2 \mathrm{H})(\mathrm{Ar}) . \delta_{\mathrm{C}}$ (100 MHz, $\left.\mathrm{C}_{6} \mathrm{D}_{6}, \mathrm{Me}_{4} \mathrm{Si}\right): 22.5,24.5\left(\mathrm{CH}_{3} \mathrm{C}, i\right.$-Pr), 29.4 (CH, $i$-Pr), 30.5 (CHC), 36.6, $44.6\left(\mathrm{CH}_{2} \mathrm{C}\right)$ (Ad), 59.5 (ipso-C, Ad), 124.2, 128.1, 128.5, 129.4, 129.5 (Ar), 127.6, 136.8, 146.3 (ipso-C, Ar), $151.5\left(\mathrm{C}^{3}\right), 211.8\left(\mathrm{C}^{5} \mathrm{~N}\right)$.

\section{trans-trans-Bis(1-tert-butyl-3-phenyl-4-p-bromophenyl-1,2,4- triazol-5-ylidene)palladium chloride (9a)}

A powder of carbene $8 \mathrm{a}^{9}(2 \mathrm{~g}, 0.56 \mathrm{mmol})$ and anhydrous dimethylsulfoxide $(0.03 \mathrm{~mL})$ were added to the suspension of palladium chloride $(0.05 \mathrm{~g}, 0.28 \mathrm{mmol})$ in THF $(5 \mathrm{~mL})$ and stirred for $0.5 \mathrm{~h}$. The suspension of complex $9 \mathrm{a}$ was evaporated to dryness and stirred with petroleum ether. The precipitate was filtered off and dried. Yield $0.25 \mathrm{~g}(100 \%), \mathrm{mp} 160-163{ }^{\circ} \mathrm{C}$ 
(subl.) (acetonitrile). Found: C, 48.7; H, 4.0; Br, 18.3; Cl, 8.1; N, 9.4. Calc. for $\mathrm{C}_{36} \mathrm{H}_{36} \mathrm{Br}_{2} \mathrm{Cl}_{2} \mathrm{~N}_{6} \mathrm{Pd}$ : C, 48.6; H, 4.1; $\mathrm{Br}, 18.0 ; \mathrm{Cl}$, 8.0; N, 9.4\%. $\delta_{\mathrm{H}}\left(400 \mathrm{MHz} ; \mathrm{CDCl}_{3} ; \mathrm{Me}_{4} \mathrm{Si}\right): 1.65\left(\mathrm{~s}, 18 \mathrm{H}, \mathrm{CH}_{3} \mathrm{C}\right)$, $7.26(\mathrm{~m}, 10 \mathrm{H}), 7.53(\mathrm{~m}, 4 \mathrm{H}) 7.69(\mathrm{~m}, 4 \mathrm{H})(\mathrm{Ar}) . \delta_{\mathrm{C}}(100 \mathrm{MHz}$, $\left.\mathrm{CDCl}_{3}, \mathrm{Me}_{4} \mathrm{Si}\right): 30.6\left(\mathrm{CH}_{3} \mathrm{C}\right), 61.9\left(\mathrm{CH}_{3} \mathrm{C}\right), 128.5,128.6,130.3$, 131.6, 132.9 (Ar), 124.0, 125.1, 136.3 (ipso-C), $151.8\left(\mathrm{C}^{3}\right), 171.3$ ( $\left.\mathrm{C}^{5} \mathrm{Pd}\right)$.

\section{Bis(1-tert-butyl-3-phenyl-4-p-bromophenyl-1,2,4-triazol-5- ylidene)palladium iodide (9b)}

The same procedure that was used for complex 9a was applied to the synthesis of $\mathbf{9 b}$. Yield $75 \%, \mathrm{mp} 119-120{ }^{\circ} \mathrm{C}$ (acetonitrile). Found: C, 40.4; H, 3.4; Br, 14.8; I, 23.6; N, 7.9. Calc. for $\mathrm{C}_{36} \mathrm{H}_{36} \mathrm{Br}_{2} \mathrm{I}_{2} \mathrm{~N}_{6} \mathrm{Pd}: \mathrm{C}, 40.3 ; \mathrm{H}, 3.4 ; \mathrm{Br}, 14.9 ; \mathrm{I}, 23.7 ; \mathrm{N}, 7.8 \%$. The product was a mixture of two isomers trans-trans- and presumably cis-trans-forms:

For the trans-trans-isomer: $\delta_{\mathrm{H}}\left(400 \mathrm{MHz}, \mathrm{CDCl}_{3}, \mathrm{Me}_{4} \mathrm{Si}\right)$ : $1.58\left(\mathrm{~s}, 18 \mathrm{H}, \mathrm{CH}_{3} \mathrm{C}\right), 7.24(\mathrm{~m}, 10 \mathrm{H}), 7.61(\mathrm{~m}, 8 \mathrm{H}, \mathrm{Ar}) . \delta_{\mathrm{C}}$ (100 MHz; $\left.\mathrm{CDCl}_{3} ; \mathrm{Me}_{4} \mathrm{Si}\right): 30.9\left(\mathrm{CH}_{3} \mathrm{C}\right), 62.2\left(\mathrm{CH}_{3} \mathrm{C}\right)$, 128.6, $128.7,130.5,132.4,132.8$ (Ar), 124.0, 125.3, 136.3 (ipso-C), $152.5\left(\mathrm{C}^{3}\right), 168.7$ ( $\left.{ }^{5} \mathrm{Pd}\right)$.

For the cis-trans-isomer: $\delta_{\mathrm{H}}\left(400 \mathrm{MHz} ; \mathrm{CDCl}_{3} ; \mathrm{Me}_{4} \mathrm{Si}\right): 2.11$ $\left(\mathrm{s}, 18 \mathrm{H}, \mathrm{CH}_{3} \mathrm{C}\right), 7.01(\mathrm{~m}, 4 \mathrm{H}), 7.33(\mathrm{~m}, 14 \mathrm{H}) ; \delta_{\mathrm{C}}(100 \mathrm{MHz}$; $\left.\mathrm{CDCl}_{3} ; \mathrm{Me}_{4} \mathrm{Si}\right): 31.9\left(\mathrm{CH}_{3} \mathrm{C}\right), 63.0\left(\mathrm{CH}_{3} \mathrm{C}\right), 128.5,128.6,130.3$, 131.4, 132.0 (Ar), 123.4, 125.5, 136.1 (ipso-C), $152.8\left(\mathrm{C}^{3}\right), 167.7$ ( $\left.\mathrm{C}^{5} \mathrm{Pd}\right)$.

The trans-trans-isomer was isolated from the mixture by additional recrystallization from acetonitrile and identified by X-ray diffraction study.

\section{Bis-[1-(1-adamantyl)-3-phenyl-4-(2,4,6-trimethylphenyl)-1,2,4- triazol-5-ylidene]palladium iodide (9c)}

The powder carbene $\mathbf{8 b}(0.4 \mathrm{~g}, 1 \mathrm{mmol})$ was added to a solution of palladium iodide $(0.18 \mathrm{~g}, 0.5 \mathrm{mmol})$ in THF $(4 \mathrm{~mL})$, the mixture was stirred for $30 \mathrm{~h}$ and boiled for $2 \mathrm{~h}$. The precipitate formed was filtered off and dried. Yield $0.42 \mathrm{~g}(72 \%), \mathrm{mp}>$ $300{ }^{\circ} \mathrm{C}$ (dimethylformamide). Found: C, 56.3; H, 5.3; I, 21.9; N, 7.4\%. Calc. for $\mathrm{C}_{54} \mathrm{H}_{62} \mathrm{I}_{2} \mathrm{~N}_{6} \mathrm{Pd}$ : C, 56.1; H, 5.4; I, 22.0; N, 7.3\%. $\delta_{\mathrm{C}}\left(100 \mathrm{MHz} ;\right.$ solid state; DSS): 21.3, $23.7\left(o-\mathrm{CH}_{3} \mathrm{C}\right), 24.6$ $\left(p-\mathrm{CH}_{3} \mathrm{C}\right), 30.9$ (CHC, Ad), 37.8, $45.2\left(\mathrm{CH}_{2} \mathrm{C}, \mathrm{Ad}\right), 64.1$ (ipso-C, Ad), 127.7, 130.0, 131.2, 133.3, 135.6, 139.8, 140.7 (Ar), 154.8 $\left(\mathrm{C}^{3}\right), 168.2\left(\mathrm{C}^{5} \mathrm{Pd}\right)$.

Bis[1-tert-butyl-3-phenyl-4-(2,6-diisopropylphenyl)-1,2,4-triazol5 -ylidene]palladium iodide (9d)

The powder palladium iodide $(0.12 \mathrm{~g}, 0.34 \mathrm{mmol})$ and dimethylsulfoxide $(0.04 \mathrm{~mL})$ were added to a solution of carbene $8 \mathrm{c}(0.25 \mathrm{~g}, 0.68 \mathrm{mmol})$ in toluene $(5 \mathrm{~mL})$, stirred at room temperature for $8 \mathrm{~h}$ and boiled for $2 \mathrm{~h}$. The precipitate that formed was filtered off, washed with petroleum ether, and dried. Yield $0.29 \mathrm{~g}(78 \%), \mathrm{mp} 260-261{ }^{\circ} \mathrm{C}$ (acetonitrile). Found: C, 53.3; H, 5.8; I, 23.3; N, 7.7\%. Calc. for $\mathrm{C}_{48} \mathrm{H}_{62} \mathrm{I}_{2} \mathrm{~N}_{6} \mathrm{Pd}: \mathrm{C}$, $53.2 ; \mathrm{H}, 5.8 ; \mathrm{I}, 23.4 ; \mathrm{N}, 7.8 \% . \delta_{\mathrm{C}}(100 \mathrm{MHz}$; solid state; DSS): 25.5, 27.1, $27.8\left(\mathrm{CH}_{3} \mathrm{C}, i\right.$-Pr $), 31.6\left(\mathrm{CH}_{3} \mathrm{C}, t\right.$ - $\left.\mathrm{Bu}\right), 47.4,48.1$ (CHC, $i$-Pr), 64.3 ( $\left.\mathrm{CH}_{3} C, t-\mathrm{Bu}\right), 126.4,127.2,128.9,130.1,132.1$, 132.8 (Ar), 134.0, 146.7, 147.4 (ipso-C), $154.9\left(\mathrm{C}^{3}\right), 171.9$ ( $\left.\mathrm{C}^{5} \mathrm{Pd}\right)$.
[1-tert-Butyl-3-phenyl-4-(2,6-diisopropylphenyl)-1,2,4-triazol-5yliden]palladium chloride (10a)

A mixture of carbene $8 \mathrm{c}(0.25 \mathrm{~g}, 0.68 \mathrm{mmol})$ and palladium chloride $(0.12 \mathrm{~g}, 0.68 \mathrm{mmol})$ in anhydrous dimethylsulfoxide $(2.5 \mathrm{~mL})$ was stirred for 3 days. The precipitate that formed was filtered off, washed by petroleum ether, and dried. Dichloromethane $(5 \mathrm{~mL})$ and water $(5 \mathrm{~mL})$ were added to the mother liquor and stirred again. The phases that formed were then subsequently separated. The dichloromethane phase was then dried by anhydrous sodium sulfate. The solvent was evaporated; the oil that formed was stirred with petroleum ether. The precipitate that formed was filtered off and dried. Yield $0.15 \mathrm{~g}$ (41\%), mp $196-198{ }^{\circ} \mathrm{C}$ (acetonitrile). Found: C, 53.4; $\mathrm{H}$, 5.9; Cl, 13.2; N, 7.7\%. Calc. for $\mathrm{C}_{24} \mathrm{H}_{31} \mathrm{Cl}_{2} \mathrm{~N}_{3} \mathrm{Pd}$ : C, 53.5; H, 5.8; $\mathrm{Cl}, 13.2 ; \mathrm{N}, 7.8 \% . \delta_{\mathrm{H}}\left(400 \mathrm{MHz} ; \mathrm{CDCl}_{3} ; \mathrm{Me}_{4} \mathrm{Si}\right): 1$ form: $0.54 \mathrm{~d}$, $0.63 \mathrm{~d}, 1.15 \mathrm{~d}, 1.30 \mathrm{~d}\left(12 \mathrm{H}, \mathrm{CH}_{3} \mathrm{C}, J 4.8 \mathrm{~Hz}, i-\mathrm{Pr}\right), 2.29$ (9H, $t$-Bu), $2.50(\mathrm{~m}, 2 \mathrm{H}, \mathrm{CHC}, i$-Pr); 2 form: $0.57 \mathrm{~d}, 0.71 \mathrm{~d}, 1.38 \mathrm{~d}$, $1.53 \mathrm{~d}\left(12 \mathrm{H}, \mathrm{CH}_{3} \mathrm{C}, J 4.8 \mathrm{~Hz}, i-\mathrm{Pr}\right), 2.18(9 \mathrm{H}, t-\mathrm{Bu}), 2.61(\mathrm{~m}, 2 \mathrm{H}$, CHC, $i$-Pr); a general part of two forms: 7.17 (m, 4H), 7.26-7.48 $(\mathrm{m}, 3 \mathrm{H}), 7.26(\mathrm{~m}, 1 \mathrm{H})(\mathrm{Ar}) . \delta_{\mathrm{C}}\left(100 \mathrm{MHz}, \mathrm{CDCl}_{3}, \mathrm{Me}_{4} \mathrm{Si}\right): 25.1$, 25.4, 28.4, 28.6, $28.7\left(\mathrm{CH}_{3} \mathrm{C}, i\right.$-Pr), $31.0\left(\mathrm{CH}_{3} \mathrm{C}, t\right.$-Bu), 24.3, 24.5 (CH, $i$-Pr), $64.3\left(\mathrm{CH}_{3} \mathrm{C}, t\right.$-Bu) $125.3,125.7,127.9,128.4,130.9$ (Ar), 131.3, 132.1, 146.8, 147.2 (ipso-C, Ar), $149.1\left(\mathrm{C}^{3}\right), 153.3$ $\left(\mathrm{C}^{5} \mathrm{Pd}\right)$.

[1-tert-Butyl-3-phenyl-4-(2,6-diisopropylphenyl)-1,2,4-triazol-5yliden]palladium iodide (10b)

A solution of carbene $8 \mathrm{c}(0.25 \mathrm{~g}, 0.68 \mathrm{mmol})$ and anhydrous dimethylsulfoxide $(0.03 \mathrm{~mL})$ in anhydrous toluene $(1 \mathrm{~mL})$ was added to a mixture of palladium iodide $(0.246 \mathrm{~g}, 0.68 \mathrm{mmol})$ in toluene $(5 \mathrm{~mL})$ and stirred for $8 \mathrm{~h}$. Then the mixture was boiled for $2.5 \mathrm{~h}$. The precipitate that formed was filtered off, washed with petroleum ether, and dried. Yield $0.40 \mathrm{~g}(81 \%)$, mp 254-255 ${ }^{\circ} \mathrm{C}$ (acetonitrile). Found: C, 40.0; H, 4.2; I, 35.1; N, 5.9\%. Calc. for $\mathrm{C}_{24} \mathrm{H}_{31} \mathrm{I}_{2} \mathrm{~N}_{3} \mathrm{Pd}$ : C, 39.9; H, 4.3; I, 35.2; N, 5.8\%. $\delta_{\mathrm{H}}\left(400 \mathrm{MHz} ; \mathrm{CDCl}_{3} ; \mathrm{Me}_{4} \mathrm{Si}\right): 1$ form: $0.62 \mathrm{~d}, 1.36 \mathrm{~d}(12 \mathrm{H}$, $\mathrm{CH}_{3} \mathrm{C}, J 4.8 \mathrm{~Hz}, i$-Pr), 2.94 (m, $2 \mathrm{H}, \mathrm{CHC}, i$-Pr); 2 form: $0.83 \mathrm{~d}$, $1.25 \mathrm{~s}\left(12 \mathrm{H}, \mathrm{CH}_{3} \mathrm{C}, J 4.8 \mathrm{~Hz}, i\right.$-Pr), 4.11 (s, 2H, CHC, $i$-Pr); a general part of two forms: $2.09(\mathrm{~s}, 9 \mathrm{H}, t-\mathrm{Bu}), 7.19(\mathrm{~m}, 2 \mathrm{H}), 7.30$ $(\mathrm{m}, 2 \mathrm{H}), 7.39(\mathrm{~m}, 3 \mathrm{H}), 7.60(\mathrm{~m}, 1 \mathrm{H})(\mathrm{Ar}) . \delta_{\mathrm{C}}(100 \mathrm{MHz}$; solid state; DSS): 23.7, 25.8, 26.5, 27.2, $29.6\left(\mathrm{CH}_{3} \mathrm{C}, i\right.$-Pr $), 31.7,32.3$ $\left(\mathrm{CH}_{3} \mathrm{C}, t-\mathrm{Bu}\right), 47.3$ (CHC, $\left.i-\mathrm{Pr}\right), 64.5\left(\mathrm{CH}_{3} \mathrm{C}, t-\mathrm{Bu}\right), 126.0,127.7$, 128.6, 131.0, 131.5, 132.7, 134.2, 136.3, 137.3 (Ar), 146.6, 147.2, 149.2, 154.2 (ipso-C), 156.1, $157.6\left(\mathrm{C}^{3}\right), 167.0,169.2,170.0$, $171.3\left(\mathrm{C}^{5} \mathrm{Pd}\right)$.

\section{[1-(1-Adamantyl)-3-phenyl-4-(2,6-diisopropylphenyl)-1,2,4- triazol-5-ylidene]palladium chloride (10c)}

A solution of carbene $\mathbf{8 d}(0.2 \mathrm{~g}, 0.455 \mathrm{mmol})$ in toluene $(1 \mathrm{~mL})$ and anhydrous dimethylsulfoxide $(0.03 \mathrm{~mL})$ was added to a suspension of palladium chloride $(0.08 \mathrm{~g}, 0.455 \mathrm{mmol})$ in anhydrous toluene $(4 \mathrm{~mL})$ for $10 \mathrm{~min}$, and the mixture was stirred for $8 \mathrm{~h}$. The precipitate that formed was filtered off, washed by petroleum ether, and dried. Yield $0.19 \mathrm{~g}(68 \%), \mathrm{mp}$ $146^{\circ} \mathrm{C}$ (dec.) (acetonitrile). Found: C, 58.3; H, 6.1; Cl, 11.5; N, 
6.9. Calc. for $\mathrm{C}_{30} \mathrm{H}_{37} \mathrm{Cl}_{2} \mathrm{~N}_{3} \mathrm{Pd}$ : C, 58.4; $\mathrm{H}, 6.0 ; \mathrm{Cl}, 11.5 ; \mathrm{N}, 6.8 \%$. $\delta_{\mathrm{H}}\left(400 \mathrm{MHz}, \mathrm{CDCl}_{3}, \mathrm{Me}_{4} \mathrm{Si}\right): 0.65 \mathrm{~s}, 13.8 \mathrm{~s}\left(12 \mathrm{H}, \mathrm{CH}_{3} \mathrm{C}, i-\mathrm{Pr}\right)$, 2.25 (m, 9H, Ad), 2.62 (m, 6H, Ad; 2H, CHC, $i$-Pr), 7.19-7.60 $(\mathrm{m}, 8 \mathrm{H}, \mathrm{Ar}) . \delta_{\mathrm{C}}\left(100 \mathrm{MHz} ; \mathrm{CDCl}_{3} ; \mathrm{Me}_{4} \mathrm{Si}\right): 24.0\left(\mathrm{CH}_{3} \mathrm{C}, i-\mathrm{Pr}\right)$, 24.4 (CH, $i$-Pr), 28.5 (CH, Ad), 31.3, 41.0 ( $\mathrm{CH}_{2}, \mathrm{Ad}$ ), 64.2 (ipso-C, Ad), 125.4, 125.6, 127.9, 128.5, 130.9 (Ar), 131.4, 132.1, 147.0 (ipso-C), $149.1\left(\mathrm{C}^{3}\right), 153.3\left(\mathrm{C}^{5} \mathrm{Pd}\right) . \delta_{\mathrm{C}}(100 \mathrm{MHz}$; solid state; DSS): 26.2, 27.1, 29.6, $31.0\left(\mathrm{CH}_{3} \mathrm{C}, i\right.$-Pr $), 31.0,36.6,44.5\left(\mathrm{CH}_{2}\right.$, Ad), 41.8, 48.6 (CH, i-Pr), 65.6 (ipso-C, Ad), 126.0, 127.2, 130.5, 131.9, 133.2 (ipso-C, Ar), $148.2\left(\mathrm{C}^{3}\right), 154.9\left(\mathrm{C}^{5} \mathrm{Pd}\right)$.

[1-(1-Adamantyl)-3-phenyl-4-(2,6-diisopropylphenyl)-1,2,4triazol-5-yliden]palladium iodide (10d)

A mixture of carbene $8 \mathbf{d}(0.25 \mathrm{~g}, 0.55 \mathrm{mmol})$, palladium iodide $(0.19 \mathrm{~g}, 0.55 \mathrm{mmol})$ and anhydrous dimethylsulfoxide $(0.3 \mathrm{~mL})$ in anhydrous toluene $(5 \mathrm{~mL})$ was stirred for $4 \mathrm{~h}$, and then the mixture was boiled for $3 \mathrm{~h}$. The precipitate that formed was filtered off, washed by petroleum ether, and dried. Yield $0.37 \mathrm{~g}$ (84\%), $\mathrm{mp}>310{ }^{\circ} \mathrm{C}$ (dimethylformamide). Found: C, 45.0; $\mathrm{H}$, 4.8; I, 31.6; N, 5.2\%. Calc. for $\mathrm{C}_{30} \mathrm{H}_{37} \mathrm{I}_{2} \mathrm{~N}_{3} \mathrm{Pd}$ : C, 45.1; H, 4.7; I, 31.7; N, 5.3\%. $\delta_{\mathrm{C}}(100 \mathrm{MHz}$; solid state; DSS): 26.9, 27.6, 29.0, $29.9\left(\mathrm{CH}_{3} \mathrm{C}, i\right.$-Pr $), 31.6,37.5,43.3\left(\mathrm{CH}_{2}, \mathrm{Ad}\right), 47.5,49.1(\mathrm{CH}$, $i$-Pr), 66.2 (ipso-C, Ad), 125.7, 128.0, 129.0, 130.5, 130.9, 132.0, 133.2 (Ar), 136.3, 146.9, 148.6 (ipso-C, Ar), $156.4\left(\mathrm{C}^{3}\right), 169.5$ $\left(\mathrm{C}^{5} \mathrm{Pd}\right)$.

\section{Acknowledgements}

We thank the Ukrainian Academy of Sciences for financial support (Grant no. 118, 26.02.2014), and the generous financial support provided by the Robert A. Welch Foundation (Grant F-0003) (A.H.C.).

\section{Notes and references}

1 Y. Cheng and O. Meth-Cohn, Chem. Rev., 2004, 104, 2507.

2 (a) D. Enders, O. Niemeier and A. Henseler, Chem. Rev., 2007, 107, 5606; (b) N-Heterocyclic Carbenes in Synthesis, ed. S. P. Nolan, Wiley VCH Verlag GmbH \& Co KgaA, Weinheim, 2006, p. 68; (c) J. Izquierdo, G. E. Hutson, D. T. Cohen and K. A. Scheidt, Angew. Chem., Int. Ed., 2012, 51, 11686; (d) M. J. Fuchter, Chem. - Eur. J., 2010, 16, 12286; (e) P.-C. Chiang and J. Y. W. Bode, in RSC Catalysis Series No. 6: N-Heterocyclic Carbenes: From Laboratory Curiosities to Efficient Synthetic Tools, ed. S. Diez-Gonzalez, Royal Society of Chemistry, 2013, ch. 14, p. 399.

3 N. I. Korotkikh and O. P. Shvaika, Carbene and carbene complex catalysis of organic reactions, DonNU, Donetsk, Ukraine, 2013, p. 372.

4 (a) D. Bourissou, O. Guerret, F. P. Gabbaï and G. Bertrand, Chem. Rev., 2000, 100, 39; (b) M. C. Jahnke and F. E. Hahn, in RSC Catalysis Series No. 6: N-Heterocyclic Carbenes: From Laboratory Curiosities to Efficient Synthetic Tools, ed. S. DiezGonzalez, RSC, 2013, ch. 1, p. 1; (c) D. Martin, M. Melaimi,
M. Soleilhavoup and G. Bertrand, Organometallics, 2011, 30, 5304; (d) W. Kirmse, Angew. Chem., Int. Ed., 2010, 49, 8798.

5 D. Enders, K. Breuer, G. Raabe, J. Runsink, J. H. Teles, J. P. Melder, K. Ebel and S. Brode, Angew. Chem., Int. Ed. Engl., 1995, 34(9), 1021.

6 D. Enders, K. Breuer, J. Runsink and J. H. Teles, Liebigs Ann. Chem., 1996, 2019.

7 N. I. Korotkikh, G. F. Rayenko, O. P. Shvaika, T. M. Pekhtereva, A. H. Cowley, J. N. Jones and C. L. B. Macdonald, J. Org. Chem., 2003, 68(14), 5762 .

8 N. I. Korotkikh, O. P. Shvaika, G. F. Rayenko, A. V. Kiselyov, A. V. Knishevitsky, A. H. Cowley, J. N. Jones and C. L. B. Macdonald, ARKIVOC, 2005, 8, 10.

9 N. I. Korotkikh, N. V. Glinyanaya, A. H. Cowley, J. A. Moore, A. V. Knishevitsky, T. M. Pekhtereva and O. P. Shvaika, ARKIVOC, 2007, 16, 156.

10 N. I. Korotkikh, A. H. Cowley, J. A. Moore, N. V. Glinyanaya, I. S. Panov, G. F. Rayenko, T. M. Pekhtereva and O. P. Shvaika, Org. Biomol. Chem., 2008, 1, 195.

11 A. V. Knishevitsky, N. I. Korotkikh, A. H. Cowley, J. A. Moore, T. M. Pekhtereva, O. P. Shvaika and G. Reeske, J. Organomet. Chem., 2008, 693, 1405.

12 A. V. Kiselyov, N. I. Korotkikh, A. H. Cowley, J. A. Moore, T. M. Pekhtereva and O. P. Shvaika, ARKIVOC, 2008, 15, 329.

13 C. Dash, M. M. Shaikh, R. J. Butcher and P. Ghosh, Dalton Trans., 2010, 39, 2515.

14 V. Hornillos, J. Guerra, A. de Cózar, P. Prieto, S. Merino, M. A. Maestro, E. Diez-Barra and J. Tejeda, Dalton Trans., 2011, 40, 4095.

15 J. Turek, I. Panov, M. Horáček, Z. Černošek, Z. Padělková and A. Růžička, Organometallics, 2013, 32, 7234.

16 T. I. Gorbunov, V. I. Saloutin and O. N. Chupakhin, Russ. Chem. Rev., 2010, 79(6), 565.

17 C. L. Geiger, K. Carvalho-Knighton, S. Novaes-Card, P. Maloney and R. DeVor, in Environmental Applications of Nanoscale and Microscale Reactive Metal Particles, ACS Symposium Series, American Chemical Society, Washington, DC, 2010, p. 1-20.

18 V. Dichiarante, M. Fagnoni and A. Albini, Green Chem., 2009, 11, 942.

19 K. A. Cannon, M. E. Geuther, C. K. Kelly, S. Lin and A. H. R. MacArthur, Organometallics, 2011, 30, 4067.

20 W. M. Czaplik, S. Grupe, M. Mayer and A. J. von Wangelin, Chem. Commun., 2010, 46, 6350.

21 Y. Mitoma, T. Uda and N. Egashira, Environ. Sci. Technol., 2004, 38, 1216.

22 Y. Mitoma, M. Kakeda, A. M. Simion, N. Egashira and C. Simion, Environ. Sci. Technol., 2009, 43, 5952.

23 A. M. Simion, H. Miyata, M. Kakeda, N. Egashira, Y. Mitoma and C. Simion, Sep. Purif. Technol., 2013, 103, 267.

24 Y. Huang, S. Liu, Z. Lin, W. Li, X. Li and R. Cao, J. Catal., 2012, 292, 111. 
25 P. Selvam, S. U. Sonavane, S. K. Mohapatra and R. V. Jayaram, Tetrahedron Lett., 2004, 45, 3071.

26 M. S. Viciu, G. A. Grasa and S. P. Nolan, Organometallics, 2001, $20(16), 3607$.

27 O. Navarro, H. Kaur, P. Mahjoor and S. P. Nolan, J. Org. Chem., 2004, 69(9), 3173.

28 O. Navarro, N. Marion, Y. Oonishi, R. A. Kelly and S. P. Nolan, J. Org. Chem., 2006, 71(2), 685.

29 C. J. E. Davies, M. J. Page, C. E. Ellul, M. F. Mahon and M. K. Whittlesey, Chem. Commun., 2010, 46, 5151.

30 S. Kuhl, R. Schneider and Y. Fort, Adv. Synth. Catal., 2003, 345(3), 341.

31 S. Akzinnay, F. Bisaro and C. S. J. Cazin, Chem. Commun., 2009, 5752.

32 N. I. Korotkikh, V. Sh. Saberov, A. V. Kiselev, N. V. Glinyanaya, K. A. Marichev, T. M. Pekhtereva,
G. V. Dudarenko, N. A. Bumagin and O. P. Shvaika, Chem. Hetercycl. Compd., 2012, 47(12), 1551.

33 X. Chen, R. Liu, Y. Xu and G. Zou, Tetrahedron, 2012, 68, 4813.

34 N. I. Korotkikh, G. F. Raenko, T. M. Pekhtereva, O. P. Shvaika, A. H. Cowley and J. N. Jones, Russ. J. Org. Chem., 2006, 42(12), 1822.

35 (a) G. M. Sheldrick, SHELXTL-PC, version 5.03, Siemens Analytical X-ray Instruments, Inc., Madison, WI, 1994. See also; (b) G. M. Sheldrick, Acta Crystallogr., Sect. A:Fundam. Crystallogr., 2008, 64, 112.

36 A. L. Spek, PLATON, A Multipurpose Crystallographic Tool, Utretcht University, The Netherlands, 1998.

37 N. I. Korotkikh, A. V. Kiselyov, A. V. Knishevitsky, G. F. Rayenko, T. M. Pekhtereva and O. P. Shvaika, Chem. Heterocycl. Compd., 2005, 7, 1026. 